\title{
Cinsiyetçiliği Azaltmaya Yönelik Müdahale Çalışmalarına İliş̧kin Eleştirel Bir Değerlendlirme ve Bir Sınıflandırma Önerisi
}

\section{A Critical Evaluation of Intervention Studies for Reducing Sexism and a Suggestion for a Classification}

\author{
Nihan Selin Soylu-Konak ${ }^{1}$ [) İbrahim Mert Teközel² (]
}

${ }^{1}$ Ar. Gör, Ege Üniversitesi, Edebiyat Fakültesi Psikoloji Bölümü, İzmir-Türkiye

${ }^{2}$ Doç. Dr., Ege Üniversitesi, Edebiyat Fakültesi Psikoloji Bölümü, İzmir-Türkiye

ORCID: N.S.S. 0000-0002-2653-9237; I.M.T. 0000-0002-2224-1425

\section{Sorumlu yazar/Corresponding author:} Nihan Selin Soylu,

Ege Üniversitesi, Edebiyat Fakültesi Psikoloji Bölümü, İzmir-Türkiye

E-posta/E-mail: nihanselinsoylu@gmail.com

Başvuru/Submitted: 30.09 .2020 Revizyon Talebi/Revision Requested: 07.03.2021

Son Revizyon/Last Revision Received: 29.07.2021

Kabul/Accepted: 26.08 .2021

Online Yayın/Published Online: 14.12.2021

Citation/Atıf: Soylu, N.S. ve Tekozel, I.M. (2021). Cinsiyetçiliği azaltmaya yönelik müdahale çalıșmalarına ilișkin eleștirel bir değerlendirme ve bir sınıflandırma önerisi. Psikoloji Çalıșmaları - Studies in Psychology, 41(3), 817-853.

https://doi.org/10.26650/SP2020-802511
ÖZ

Toplumsal cinsiyet kalıp yargıları ve cinsiyetçilik, politika düzeyinde 60'lardan, sosyal psikoloji alanyazınında ise 70'lerden itibaren mesele haline getirilmiştir. Cinsiyetçiliğin pek çok sosyal psikolojik değişkenle olan ilişkileri ve yaşam doyumu, eğitim imkanları gibi pek çok yaşamsal konudaki etkileri uzun yıllardır çalış1lıyor olsa da cinsiyetçiliği azaltmaya yönelik müdahale çalışmalarına bakıldığında alanyazının henüz bir uzlaşıya varamadığı görülmektedir. Bu çalışmanın temel amacı, alanyazında cinsiyetçiliğin etkilerinin halen sürdüğünü gösteren güncel çalışmaları ve müdahale çalışmalarını derlemenin yanı sıra, müdahale çalışmalarında gözlenen yöntemsel ve kuramsal kısıtlılıklara işaret ederek gelecek çalışmalar için yeni bir sınıflandırma modeli önermektir. Sınıflandırma modeline göre cinsiyetçiliği azaltmayı hedefleyen müdahale çalışmaları, (1) cinsiyet belirten bir uyaranın algılanması sürecine müdahale (2) cinsiyet bilgisinin (örtük veya açık bir şekilde) kişilik özellikleriyle (veya rollerle) ilişkilendirilmesi sürecine müdahale (3) (açık, gizil veya örtük) cinsiyetçi tutumlara müdahale ve (4) cinsiyetçi davranışlara müdahale olmak üzere dört temel boyutta ele alınabilir. $\mathrm{Bu}$ modelin temel amacı cinsiyetçiliği azaltmayı hedefleyen müdahale çalışmalarında gözlenen kavramsal dağınıklık, bulguların uyuşmazlığı ve düşük karşılaştırılabilirlik gibi sorunları en aza indirgemektir. Müdahale çalışmalarında bu modelin hesaba katılması, modelin öngördüğü boyutların hem tek tek hem de birbirleri ile geçişlilikleri çerçevesinde ele alınıp, elde edilen bulguların karşılaştırılabilirliğine katkı sağlayarak alanyazının birikimli ilerlemesine yardımcı olabilir. Ayrıca kullanılan müdahale tekniklerinin cinsiyetçiliğin farklı boyutlarında farklı örüntülerle etki göstermesine (örn., cinsiyetçiliğin bir boyutunda azalmaya, başka bir boyutunda ise artmaya sebep olması) yol açan potansiyel sebeplerin tespit edilmesi ve cinsiyetçi tutumlar ve davranışlar arasındaki karmaşık ilişkilerin anlaşılması kolaylaşabilir. Son olarak, önerilen dört boyutlu sınıflandırma modeli, cinsiyetçiliği konu alan kuramlar ve müdahale çalışmaları çerçevesinde yapılandırılarak tartışılmıştır.

Anahtar Kelimeler: Toplumsal cinsiyet kalıp yargıları, çelişik duygulu cinsiyetçilik, örtük cinsiyet kalıp yargıları, cinsiyetçilik, müdahale çalışmaları, sınıflandırma modeli 


\section{ABSTRACT}

Gender stereotypes and sexism has been a topic of discussion in politics and social psychology since the 1960s. The relationships between sexism and various social-psychological variables, as well as the effects of sexism and gender stereotypes on life satisfaction and accessibility of educational opportunities, have been examined. Therefore, previous research on sexism-reduction intervention has not reached a consensus. The major goal of this research is to review intervention studies and the current literature on the effects of sexism, as well as draw attention to the theoretical and methodological limitations of intervention studies and suggest a new classification model for future studies. According to this classification model, intervention studies addressing sexism can be classified into four basic dimensions: (1) intervention to the process of perceiving a stimulus containing sex information; (2) intervention to (implicitly or explicitly) the process of binding sex information to traits; (3) intervention to (explicit, subtle or implicit) sexist attitudes; and (4) intervention to sexist behavior. The essential aims of this model are to reduce the conceptual challenges and discrepancy between the findings and minimize the low comparability of such findings in the intervention studies. Considering various dimensions categorically and the transactions between the dimensions suggested in this model can contribute to the cumulative progress of relevant literature by providing comparable standards for results from different intervention studies. However, this model can facilitate an understanding of not only contradictory patterns of different intervention methods on various dimensions (e.g., reducing sexism on one dimension and increasing on another dimension) but also the complex relationships between sexist attitudes and behaviors. Lastly, the suggested fourdimension classification model was discussed within the scope of sexism theories and empirical intervention studies; focusing on sexism.

Keywords: Gender stereotypes, ambivalent sexism, implicit sexism, intervention studies, the model for classification of sexism

\section{EXTENDED ABSTRACT}

Several theories explain the mechanisms underlying sexism. In this research, we examined commonly accepted theories that are effective in intervening in sexism like the modern sexism theory (Swim, Aikin, Hall, \& Hunter, 1995) and ambivalent sexism theory (Glick \& Fiske, 1996).

However, though sexism has been examined in social psychology for over 50 years, intervention studies for reducing sexism are limited and are yet to reach a consensus. Regarding intervention studies, two main perspectives stand out. The first focuses on explicit sexist attitudes and behaviors, while the second focuses on implicit sexist attitudes and gender stereotyping schemas.

Nevertheless, awareness of one's sexist attitudes and gender stereotypes is one of the most salient and influential factors in intervention studies (e.g., Kilmartin et al., 2008). Some persons are not aware of their sexist attitudes (Bargh, Chen, \& Burrows, 1996; Blair \& Banaji, 1996), so creating awareness will reduce sexism (Case, Hensley, \& Anderson, 2014; Good \& Woodzicka, 2010). Conversely, creating awareness will increase sexism by activating gender stereotypes (e.g., Tinkler, Li, \& Mollborn, 2007). However, though awareness has a crucial potential in reducing sexism, the actual effects of awareness of various dimensions of sexism should be examined intently. 
In addition to the conceptualization of sexism (implicit or explicit), there are some methodological issues in the intervention studies (e.g., the method of intervention, demand characteristics, ecological validity), which can cause inconsistent findings. Thus, the confusing effects of conceptualization and methodological issues in interventions are discussed, and a new model of classification is suggested.

\section{Classification Model for the Intervention Studies}

Regarding the literature on interventions for reducing sexism, the most notable fact is that the findings of interventions have a low effect (e.g., Case et al., 2014), or no effect (e.g., Kilmartin, Semelsberger, Dye, Boggs, \& Kolar, 2015) and even worse undesired effects (e.g., Freedman, Seidman, Flanagan, Kaufman, \& Green, 2018). However, the literature on interventions also points to several promising avenues (e.g., Dasgupta \& Asgari, 2004). The common ground of successful interventions is that they reduce not only the sexist outputs (e.g., behavior) but also the effects of mediating cognitive structures (e.g., Blair, Ma, \& Lenton, 2001). Here, it is suggested to construct interventions to reduce four dimensions of sexism: (1) intervention for the process of perceiving a stimulus containing sex information; (2) intervention for (implicitly or explicitly) the process of binding sex information to traits;

(3) intervention for (explicit, subtle, or implicit) sexist attitudes; and (4) intervention for sexist behavior.

Intervention for the process of perceiving a stimulus containing sex information. Gender stereotypes affect the coding of new information about others. The information consistent with gender stereotypes is more robustly coded (Newall et al., 2018; Proverbio, Alberio \& De Bendetto, 2018; Yan, Wang \& Zhang, 2012). This dimension can be assumed to be the first step; therefore, intervention aiming to reduce the sexist biases in this dimension has great potential. However, this dimension was examined without monitoring the effects on the other three processes.

Intervention for (implicitly or explicitly) the process of binding sex information to traits. Individuals are prone to remember the stereotypic information more robustly (Berthold, Steffens, \& Mummendey, 2019; Huang \& Sherman, 2018). For instance, a new manuscript in a Turkish sample showed that traits such as "talkative" were more robustly bound with women actors, and inferences were made in a gender stereotypic way by more sexist participants (Soylu, 2017). Regarding these inferences and bindings as a ground for attitudes and behaviors, the critical role of these structures is clearly on the course to reduce sexism.

Intervention for sexist attitudes. Most of the intervention studies in the literature reduced this dimension of sexism; however, discrepant findings were obtained. Two major problems are the confusion regarding which type(s) of attitudes are chosen and the current 
validity of chosen attitude type in this era. Involving all types of attitudes in intervention studies is essential because these different types can be processed in various ways (e.g., Tinkler et al., 2007). Besides, the chosen types of attitudes targeted in the intervention should be up-to-date, and standardization of measurements should be done to attain comparable results.

Intervention for sexist behavior. Although attitudes are approached as determinants of behaviors, the mediator variables within this relationship are not yet understood (See Armitage \& Christian, 2003; McConnell \& Leibold, 2001). Therefore, this dimension can be evaluated as an output of the first three types considering that directly aiming at sexist behavior in interventions has great potential in reducing sexism.

\section{Discussion}

The findings of intervention studies show that it is necessary to be meticulous when establishing the method and dimension of intervention. Because aside from the ineffectiveness, there can be unintended consequences (Freedman et al., 2018; Hilliard \& Liben, 2010; Tinkler et al., 2007). The classification model in the current study can make more comparability possible between the findings and explain the mechanisms between various dimensions of sexism. Therefore, intervention studies can have a cumulative effect that can reduce and eventually terminate sexism. 
Cinsiyetçiliği azaltmaya yönelik çabalar oldukça uzun bir süredir sosyal psikolojinin gündeminde yer almasına ve bu konudaki sosyal müdahale çalışmalarının giderek yaygınlaşmasına rağmen kişilerarası düzeyde yeterince çarpıcı bir ilerleme sağlanamadığı görülmektedir (örn., Avcil, 2020; Charlesworth, Yang, Mann, Kurdi ve Banaji, 2021). Şüphesiz ki, sosyal psikologların (daha genel anlamda sosyal bilimcilerin) çabaları cinsiyete dayalı ayrımcılığın daha görünür olmasına, cinsiyet eşitsizlikleri konusunda toplumsal duyarlılığın artmasına, bu konudaki idari ve yasal düzenlemelerin gelişmesine dolaylı da olsa katkı sağlamıştır. Ancak gelinen nokta tatmin edici olmaktan uzaktır. Cinsiyete dayalı ayrımcılık, ülkemiz dahil pek çok toplumda önde gelen problemlerden biri olmayı sürdürmektedir (Dang ve Nguyen, 2021; ECOSOC, 2019; Yüksel-Kaptanoğlu, Arslan ve Akyıldırım, 2021). Bunun böyle olmasının çok boyutlu (siyasi, ekonomik, yönetimsel vs.) nedenleri olduğu açık olmakla birlikte, bu çalışma kapsamında olgunun kişilerarası yönlerine odaklanılacak, sosyal psikolojinin cinsiyet açısından eşitlikçi olmayan tutum ve davranışları değiştirmeye yönelik etkinliklerinin eleştirel bir değerlendirmesi yapılacaktır. Başka bir deyişle, bu çalışmanın temel amacı, cinsiyetçiliği azaltmaya yönelik gerçekleştirilen müdahale çalışmalarını değerlendirmek ve bu alanda gözlenen sorunlara işaret ederek çözüm önerileri sunmaktır. Öncelikle cinsiyetçiliği açıklamaya çalışan kuramlar arasında müdahale çalışmalarında yaygın olarak temel alınan kuramlar tanıtılacak, ardından alanyazında yer alan müdahale çalışmalarından temsil ediciliği yüksek bulunan çalışmalar özetlenerek gözlenen sorunlar tartışılacak ve son olarak da söz konusu sorunları en aza indirgemeyi amaçlayan bir sınıflandırma modeli önerilecektir.

\section{Toplumsal Cinsiyet Kalıp Yargıları ve Cinsiyetçilik}

Kalıp yargılar, insanların dünyayı ve diğerlerini anlamak için kullandıkları basit kısayollar olarak tanımlanabilir. Diğerleriyle ilgili izlenimler oluşturulurken çok fazla uyaranın mevcut olması nedeniyle, kolayca izlenim oluşturabilmek ve diğerlerine ilişkin çıkarımlara hızlıca ulaşabilmek için bu kısayollara ihtiyaç duyulmaktadır (Bilgin, 2014; Bodenhausen, 1990). Kalıp yargılar pek çok bilişsel yapı gibi bazı işlevler görmek üzere (örn., sosyal kategorilere ilişkin beklentileri hızlıca düzenlemek vb.) düzenlenmiştir ve aslında kendiliğinden olumsuzluk barındırmaz (Schneider, 2005). Bununla birlikte önyargılarla olan güçlü bağı, kalıp yargıları yaklaşık yüz yıldır sosyal psikoloji alanyazınında önemli bir yere taşımıştır ve sıklıkla olumsuz etkileri bakımından ele alınmaktadır (Lamont, Swift ve Abrams, 2015; Rinehart, 1963; Taub, 1985). Cinsiyet 
ise, herhangi bir kişiye dair bilinçli veya bilinçsiz bir şekilde izlenim oluştururken ve/ veya çıkarımlarda bulunurken ilk bakışta -milisaniyeler içinde- görünebilir özelliklerden biri olması nedeniyle kalıp yargılar için en temel kaynaklardan birini oluşturmaktadır (Bkz. Fiske, 1998). Bu nedenle, kalıp yargılardan kaynaklanan olumsuz etkiler cinsiyet kalıp yargılarında çarpıcı düzeylere ulaşmaktadır.

Sosyal psikoloji alan yazınında toplumsal cinsiyet kalıp yargılarını inceleyen ilk sistematik araştırmalar 1970'lerde başlamıştır (Broverman, Broverman, Clarkson, Rosenkrantz ve Vogel, 1970; Broverman, Vogel, Broverman, Clarkson ve Rosenkrantz; 1972; Spence, Helmreich ve Stapp, 1974). Örneğin, Maccoby ve Jacklin (1974) kadınlar ve erkeklerin çok büyük ölçüde birbirleriyle benzer olduklarını; ancak kadınların sözel yeteneklerinin, erkeklerinse uzamsal yeteneklerinin daha iyi olduğu gibi bazı istisnai durumlar olduğunu öne sürmüştür. Daha sonra yapılan araştırmalar (örn., Eagly ve Mladinic, 1989; Eagly ve Steffen, 1984; Spence, Helmreich ve Stapp, 1975) kadınlar ve erkeklerin farklı kişilik özellikleri ile tanımlandıklarını göstermektedir ve bu özellikler iki farklı temel boyuta işaret etmektedir, bunlar sıcaklık (warmth) ve yetkinliktir (competence). Kadınlar sıcak, yardımsever, hassas, nazik gibi özelliklerle tarif edilirken; erkekler yetkin, bağımsız, mantıklı gibi özelliklerle tarif edilmektedir. Toplumsal cinsiyet kalıp yargıları ile ilgili Türkiye'de yapılan ilk araştırmalardan olan Kandiyoti’nin (1982) çalışması da yine kişilik özellikleri temelinde benzer sonuçlar vermiştir.

1970’lerden bu yana cinsiyet kalıp yargılarında bazı değişimler meydana gelmiştir. Temelde kadınların sıcaklık, erkeklerinse yetkinlik boyutları üzerinden tanımlanması sürüyor olsa da zaman içinde kadınlara yönelik değerlendirmelerde yetkinlik boyutunun giderek önem kazandığı görülmektedir (Diekman ve Eagly, 2000; Twenge, 1997). Cinsiyet kalıp yargılarında meydana gelen değişimlere koşut olarak cinsiyetçilik de farklı biçimlere bürünmektedir ve dolayısıyla cinsiyetçilik kuramlarında da zaman içinde farklı perspektifler geliştirilmiştir.

Cinsiyetçilik, kadın ve erkekler için eşit olmayan şekilde tarif edilen kalıp yargıların kabul edilmesi ve buna göre tutum, inanç ve davranışların geliştirilmesi olarak tanımlanabilir. Cinsiyetçiliğe maruz kalan kadınların stres, depresyon ve anksiyete gibi sorunlar1 daha sık yaşadıkları bilinmektedir (Jost ve Kay, 2005; Klonoff, Landrine ve Campbell, 2000; Swim, Hyers, Cohen ve Ferguson, 2001). Eşitlikçi olmayan toplumsal cinsiyet rollerine göre şekillenen toplumda erkekler, güç ve üstünlügü elinde bulundurmakta ve 
dolayısıyla kadınlar eğitim, iş hayatı, sağlık gibi yaşamın pek çok alanında dışlanmakta ya da ikinci planda kalmaktadır (Spence ve Hahn, 1997; Swim ve Campbell, 2003). Bu nedenle, gerek Türkiye'de gerek dünyada kadınların mağduriyetiyle daha fazla karşılaŞılmaktadır ve cinsiyetçilik konusu alanyazında sıklıkla bu yönüyle incelenmektedir (Rudman ve Glick, 2008; Sakallı-Uğurlu, 2002; 2003).

Sosyal psikoloji alanyazınında cinsiyetçiliği açıklamaya çalışan pek çok kuram mevcuttur. Bu kuramlar arasında en yaygın etkiye sahip kuramlardan biri şüphesiz ki Bem (1981) tarafindan ortaya atılan toplumsal cinsiyet şeması kuramıdır. Bu kurama göre çocukluğun erken dönemlerinde başlayan sosyalizasyon süreci esnasında cinsiyete dayalı kategorizasyon ile cinsiyet şemalarının oluşumu gerçekleşmekte ve bu şemalar yaşam boyunca sürebilmektedir. Cinsiyet şemaları, edinilen yeni enformasyonların işlenmesinden karar verme süreçlerine dek pek çok sosyal-bilişsel fonksiyonu etkilemek suretiyle davranışları da düzenler. Cinsiyetçiliği konu edinen bir başka kuram, nesneleştirme kuramı (objectification theory; Fredrickson ve Roberts, 1997) kadın bedeninin toplum tarafindan nesne haline getirilmesinin, kadınların da kendilerini bu gözle görmelerine yani kendi perspektiflerinden de nesneleştirilmelerine neden olacağını ve sonucunda utanç, anksiyete ve yeme bozukluğu gibi psikolojik sorunların ortaya çıkacağını öne sürer. Cinsiyetçiliği de kapsayan kesişimsellik kuramı (intersectionality theory; Crenshaw, 1989) ise, 1rk ve cinsiyete dayalı ayrımcılık uygulamalarının kombine hale gelen etkilerini incelemektedir. Her ne kadar güncel olarak çalışılan pek çok cinsiyetçilik kuramı mevcutsa da bu derleme kapsamında, yalnızca cinsiyetçiliğe müdahale girişimlerinde yaygın olarak başvurulan kuramlar kısaca özetlenecektir.

Modern ve Yeni Cinsiyetçilik Kuramları. Swim, Aikin, Hall ve Hunter (1995) tarafından geliştirilen modern cinsiyetçilik kuramı, değişen toplumsal yapının geleneksel cinsiyetçiliği onaylamamasından kaynaklanan yeni bir cinsiyetçilik biçimi oluştuğunu öne sürmektedir. Tıpkı 1rkçılıkta olduğu gibi, açık bir şekilde gözlenebilen ayrımcılık davranışları ve önyargılı tutumlar yeni toplumsal kurallar tarafından onaylanmayabilmektedir; fakat bu durum, ayrımcılığın ve önyargının sona ermesini sağlamamakta, eşitlikçi gibi görünen ancak aslında sadece farklılaşmış önyargılı tutumların ve ayrımcı pratiklerin oluşmasına neden olmaktadır (Gaertner ve Dovidio, 1986; McConahay, 1986). Tougas, Brown, Beaton ve Joly (1995) tarafından öne sürülen yeni cinsiyetçilik (neosexism) kuramı da yine ırkçılık alanyazınından kök almaktadır ve modern cinsiyetçilik kuramı ile çok benzer bir temele sahiptir. Bu kuram, erkeklerin cinsiyete duyarlı 
davranışları, dil kullanımı ve kariyer fırsatları gibi konulara ilişkin gerçekte eşitlikçi olmayan ancak eşitlikçi gibi görünen tutumlarını incelemekte ve geleneksel cinsiyetçilikten farklı olarak, yeni cinsiyetçiliğin toplumsal yaşamda daha çok karşılık bulduğunu göstermektedir. Benokraitis ve Feagin'e (1995) göre açık cinsiyetçilik bireyin farkında olduğu, açıkça gözlenebilen tutumları; gizil cinsiyetçilik bireyin tam anlamıyla farkında olmadığı, eşitlikçi olduğunu varsaydığı ancak ayrımcılık içeren tutumları; örtük cinsiyetçilik ise bireyin farkındalığının hiç olmadığı ancak davranışlarında gözlenebilen ayrımcı tutumları ifade etmektedir. Modern ve yeni cinsiyetçilik kuramları, gerek iş yaşamında süregelen gizil cinsiyetçiliği gerekse cinsiyete duyarlı politikalara ilişkin olumsuz tutumları incelemek için alanyazına ölçekler (örn., Modern Cinsiyetçilik Ölçeği, Yeni Cinsiyetçilik Ölçeği) kazandırmış ve cinsiyetçiliğin güncel formunun anlaşılması için kapsamlı bir teorik zemin hazırlamışlardır (Campbell, Schellenberg ve Senn, 1997).

Çelişik Duygulu Cinsiyetçilik Kuramı. Glick ve Fiske (1996; 2001) tarafindan ortaya atılan bu kuram, cinsiyete dayalı ayrımcılığın diğer ayrımcılık türlerinden farklı oluşu vurgusu üzerine temellenmektedir. Irk veya yaş gibi diğer ayrımcılık türlerinde Allport, Clark ve Pettigrew'un (1954) tarif ettiği biçimde dış grubu tamamen ötekileştirmek söz konusu iken, cinsiyete dayalı ayrımcılıkta olumsuz tutum ve duyguların yanı sıra üreme ve cinsellik ihtiyacı nedeniyle (ilk bakışta) olumlu tutum ve duygular da söz konusudur. Çelişik duygulu cinsiyetçilik kuramı, kadınlara ilişkin olumsuz tutumları düşmanca cinsiyetçilik, sözde olumlu tutumları ise korumacı cinsiyetçilik olarak adlandırır ve her ikisi de ataerkillik, cinsiyetler arası farklılaştırma ve heteroseksüellik olmak üzere üç boyut çerçevesinde ele alınmaktadır.

Düşmanca cinsiyetçilik, baskıcı ataerkillik, cinsiyetler arası yarışmacı farklılaştırma ve heteroseksüel düşmanlığı içerirken; korumacı cinsiyetçilik ise koruyucu ataerkillik, cinsiyetler arası tamamlayıcı farklılaştırma ve heteroseksüel yakınlığı içerir. Baskıcı ataerkillik kadınların erkekler tarafindan yönetilmesi gerektiği, cinsiyetler arası yarışmacı farklılaştırma ise kadınların genel olarak erkeklerden daha düşük düzeyde becerilere sahip olduğu yönündeki inanç ve görüşleri kapsar. Heteroseksüel düşmanlık ise kadınların yalnızca cinsellikle ilişkilendirilerek nesneleştirilmesini ifade eder. Korumacı cinsiyetçiliğin içerisinde yer alan koruyucu ataerkillik kadınların zayıf oldukları ve korunmaya muhtaç olduklarına ilişkin inanç ve görüşleri, cinsiyetler arası tamamlayıcı farklılaştırma iki cinsiyetin sahip olduğu farklı özelliklerle birbirlerini tamamlayabile- 
cekleri yönündeki inanç ve görüşleri, heteroseksüel yakınlık cinsel ihtiyaçlar nedeniyle kadınlara yönelik sevgiyi ifade eder (Glick ve Fiske, 1996; Sakallı-Uğurlu, 2002). Çelişik duygulu cinsiyetçilik, cinsiyetçiliği barındırdığı zıtlıklarla ve farklı boyutlarıyla ele alarak özgün bir çerçeve sunması bakımından güncel olarak oldukça sık başvurulan bir kuramdır (Glick ve Fiske, 2011; Kosterina, Horne ve Lamb, 2019; Sakall1-Uğurlu, 2002).

Gündelik Cinsiyetçilik ve Mikro-saldırganlık Kuramları. Swim ve arkadaşları (2001) tarafından öne sürülen gündelik cinsiyetçilik (everyday sexism), günlük yaşamda gömülü olarak bulunan ve kişiler arası ilişkilerde gizil biçimde ortaya çıkan ayrımcı inançları ve bunların yansımalarını ifade eder. Bu yansımalar, ayrımcılığa maruz kalan bireylerin, yani çoğunlukla kadınların psikolojik sağlık ve iyi oluş düzeylerini etkilemektedir. Ayrıca, kadınların maruz kaldığı cinsiyetçiliği geçmişe dönük olarak bildirmelerinin bellek hatalarına açık bir süreç olduğunu vurgulanarak, günlük notlar şeklinde incelenmesinin daha geçerli olacağı önerilmiştir. Bu yöntemde katılımcılar deneyimledikleri ya da şahit oldukları cinsiyetçilik içeren olayları kaydederler ve araştırmacılar tarafından anlık olarak düzenlenen soru formlarını doldururlar. Bu yöntem, katılımcıların duygularını ifade etmesini sağladığı gibi farkındalık düzeylerinin de artmasını sağlamaktadır.

Sue (2010), tarafından öne sürülen cinsiyete dayalı mikro-saldırganlık, genellikle erkekler tarafından, bilinçli veya bilinçsiz olarak gerçekleştirilen ve olumsuzluk içeren, aşağılayıcı, dışlayııı davranış veya sözleri ifade etmektedir. Deneyimlenen mikro-saldırganlık düzeyi Owen, Tao ve Rodolfa’nın (2010) geliştirdiği ölçek ile ölçülmektedir ve bu araştırmanın sonuçları deneyimlenen mikro-saldırganlık düzeyinin, psikolojik sağlık durumu ve terapötik ilişkiyi olumsuz yönde etkilediğini göstermektedir. Mikro-saldırganlık cinsiyetçiliğin hem açık hem de gizil formlarını kapsamaktadır ve özellikle iş yaşamında süregelen cinsiyetçiliği incelemek için uygun bir çerçeve sunmaktadır (Basford, Offermann ve Behrend, 2014).

Örtük Cinsiyetçilik. Örtük tutumlar, bireyin kontrolü altında olmayan, bilinci dışında bulunan inançlar, psikolojik eğilimler olarak tanımlanabilir (Aberson ve Haag, 2007; Greenwald ve Banaji, 1995). Örtük tutumlar davranışları etkiliyor olsa da insanların genellikle farkında olmadıkları bir sosyal bilişsel yapıyı ifade eder (Carnes ve ark., 2012; Chen ve Bargh, 1997). Yani, cinsiyetçilik konusunda eşitliği savunan bir bireyin 
örtük tutumları da aynı yönde olmayabilir ve bu durum farkında olmaksızın, cinsiyetçiliğe hizmet eden davranışlara neden olabilir (Bargh, Chen ve Burrows, 1996; Blair ve Banaji, 1996; Devine, 1989). Öz-bildirim yönteminden farklı olarak Örtük Çağrışım Testi ile (Implicit Association Test), yani bireylerin çeşitli uyaranlara tepkilerinin doğruluğu ve tepki süreleri ile ölçülen örtük tutumlar, çoğu zaman açık tutumlarla ya zayıf düzeyde ilişkilidir ya da ilişkili değildir (Greenwald, McGhee ve Schwartz, 1998; Hofmann, Gawronski, Gschwendner, Le ve Schmitt, 2005). Açık tutumların eşitlikçi oluşundan bağımsız olarak örtük tutumların davranışı yordadığını gösteren bulgular mevcuttur (Agerström ve Rooth, 2011; Greenwald, Poehlman, Uhlmann ve Banaji, 2009; Jackson, 2016; Nosek, 2005). Öte yandan Monteith'in (1993) araştırmasının sonuçları açık tutumlardaki eşitlikçiliğin örtük tutumları da olumlu yönde etkileyebileceğini göstermektedir. Skowronski ve Lawrence (2001) 'gerçek tutum'u, hem açık hem de örtük tutumların bir bileşimi olarak tarif etmekte ve bu iki formun birlikte incelenmesi gerekliliğini vurgulamaktadır. Bununla birlikte, toplumsal yapının değişmesi sonucunda ortaya çıkan sosyal istenirlik gibi unsurların etkilerinden kaçınmak için cinsiyetçilik alanyazınında örtük tutumların önemi giderek artmaktadır (Bkz. Lenton, Bruder ve Sedikides, 2009).

Cinsiyetçilik konusunda örtük tutumların anlaşılması noktasında önemli bir firsat sunabilecek bir kavram olarak spontane kişilik özelliği çıkarımları (SKÖÇ), diğerlerinin davranışlarından hareketle; kontrol, niyet ve farkındalık olmaksızın otomatik olarak gerçekleşen, diğerlerine ilişkin sosyal çıkarımları ifade eder (Uleman, Saribay ve Gonzalez, 2008; Winter ve Uleman, 1984). SKÖÇ, diğeri tarafından gerçekleştirilen bir davranışın gözlenmesinin zihinde bir kişilik özelliğini aktive ettiği aktivasyon aşaması ve aktive olan kişilik özelliğinin uzun süreli bellekte davranışı gerçekleştiren kişinin temsilleri arasında kaydedildiği ilişskilendirme aşaması olmak üzere iki aşamadan oluşur (Zárate, Uleman ve Voils, 2001). Örneğin, "Ayşe masaya vurdu ve ne yapılması gerektiğini söyledi.” cümlesinin 'baskın' sözcüğünü aktive etmesi ilk aşamaya, bu sözcügün Ayşe'nin temsilleri arasına kaydedilmesi ise ikinci aşamaya tekabül eder. SKÖÇ, alanyazında bir cinsiyetçilik kuramı veya ölçümü olarak ele alınmamaktadır. Ancak hem açık hem de gizil cinsiyet kalıp yargılarının SKÖÇ’ü etkilediği bilinmektedir. Toplumsal cinsiyet şemalarına daha fazla önem veren insanlar, daha az önem verenlere kıyasla aktivasyon aşamasında cinsiyet kalıp yargılarıyla uyumlu yönde SKÖÇ gerçekleştirmektedir (Yan, Wang ve Zhang, 2012). Düşmanca cinsiyetçilik ve koruyucu ataerkillik 
de ilişkilendirme aşamasında cinsiyet kalıp yargılarına daha uygun SKÖÇ’e yol açmaktadır (Soylu, 2017). SKÖÇ, Örtük Çağrışım testinde olduğu gibi tepki doğruluğu ve tepki süresi baz alınarak ölçülmektedir. Oldukça hızlı ve otomatik bir sürece tekabül etmekte ve bilişsel yük altında da gerçekleşmektedir (Todorov ve Uleman, 2003). Bu nedenlerle sosyal istenirlik faktörünün etkisini bertaraf etme gücü yüksektir (Bkz. Fazio ve Olson, 2003).

Yukarıda da bahsedildiği gibi burada alanyazında yer alan tüm cinsiyetçilik kuramlarından ziyade, müdahale çalışmalarında sıklıkla rastlanan kuramlara yer verilmiştir. Sonraki bölümde ise, araştırmacılar tarafından alanyazını temsil ediciliği yüksek bulunan müdahale çalışmaları, temel aldıkları cinsiyetçilik kuramlarına göre sıralanarak özetlenecektir.

\section{Müdahale Çalışmaları}

Cinsiyetçiliği azaltmaya yönelik müdahale çalışmaları EBSCHO, JSTOR, PsycINFO, PsycARTICLES, Sage Journals Online, Science Direct, Springer Link, Taylor and Francis Online Journals, ULAKBİM ve Wiley Online Library veri tabanlarında taranmıştır. Kullanılan anahtar kelimeler ise çeşitli kombinasyonlarıyla şunlardır: Cinsiyetçilik, cinsiyet yanlılığı, cinsiyet kalıp yargıları/stereotipleri, cinsiyetçi tutumlar, müdahale, hazırlama, azaltma, esneklik, tutum değişimi, sexism, gender bias, gender stereotypes, sexist attitudes, intervention, priming, reducing, flexibility, attitude change. Bulunan çalışmalar arasında bağımlı ölçümlerinde herhangi cinsiyetçilik düzeyi yer almayan, diğer kalıp yargı ve ayrımcılık türlerini inceleyen çalışmalar (örn., Gocłowska, Crisp ve Labuschagne, 2013) ve müdahale çalışmalarının gerekliliğini vurgulayan, kuramsal öneriler sunan çalışmalar (örn., Drury ve Kaiser, 2014) da yer almaktadır; ancak burada yalnızca görgül bulgular sunan araştırmaların bir kısmına değinilecektir. Müdahale çalışmaları incelendiğinde çok büyük bir çoğunluğunun cinsiyetçi tutumlara yönelik olduğu, tutumlar dışındaki sosyo-bilişsel yapıların (sosyal algı, şema, çıkarım yapma vb.) büyük ölçüde ihmal edildiği görülmüştür. Sosyal algı sürecinde gözlenen cinsiyetçiliği (Hugenberg ve Bodenhausen, 2004; Proverbio, Orlandi ve Bianchi, 2017) azaltmaya yönelik bir müdahale çalışmasına rastlanmamıştır. Cinsiyetçi davranışlara yönelik müdahale çalışmalarının da oldukça azınlıkta ve işe alım davranışıyla kısıtlı olduğu görülmüştür (Isaac, Lee ve Carnes, 2009; Kawakami, Dovidio ve Kamp, 2007). Tutumlara yönelik çalışmalarda ise, farklı örneklemlerde incelense de uygulanan müdahalenin yöntemsel açıdan benzerlik gösterdiği (örn., kalıp yargı karşıtı hazırlama) ve benzer 
yönde sonuçlar elde eden araştırmalardan (örn., Blair, Ma ve Lenton, 2001; McKimmie, Masters, Masser, Schuller ve Terry, 2013; Sagone, De Caroli, Coco ve Perciavalle, 2018) temsil edici bulunanlar, kuramsal bölümde kronolojik sırasıyla yer alan kuramlar bazında sıralanarak özetlenecektir.

Modern cinsiyetçilik kuramını temel alan Moss-Racusin ve arkadaşları (2016) yaz akademisinde ders veren eğitmenlerde, cinsiyet yanlılığını azaltmak üzere 'bilimsel çeşitlilik' başlığı altında iki haftalık bir çalıştay hazırlamışlardır. Bu çalıştay dört unsur çerçevesinde hazırlanmıştır: (1) var olan teorik ve görgül verilere dayalı olması, (2) aktif öğrenme tekniğinden faydalanması, (3) çeşitliliği paylaşılan bir amaç olarak sunması ve suçlamadan kaçınması, (4) müdahalenin etkililiğinin tartışılması. Cinsiyet yanlılı̆̆ını ise, çeşitlilik konusunda farkındalık düzeyi ("Bölümünüzde ne kadar çeşitlilik olduğunu düşünüyorsunuz?”), modern cinsiyetçilik düzeyi ve eyleme hazır olma (action readiness) düzeyi (örn., "Amaçlarımın peşinden gitmek için kendimi yeterince güvende hissediyorum/hata yapmaktan çekiniyorum.") ile ölçmüşlerdir. Sonuçlara göre, gerçekleştirilen müdahale, farkındalık düzeyinin artmasını, modern cinsiyetçilik düzeyinin düşmesini ve eyleme geçme eğiliminin artmasını sağlamıştır. Araştırmacılar, müdahalenin başarısının gelecek çalışmalar için iyi bir temel oluşturduğunu vurgulamış, ancak çalıştıkları örneklemin gönüllü eğitmenlerden oluştuğunu ve bu modelin başka örneklemlerde de incelenmesi gerektiğini öne sürmüşlerdir.

Modern cinsiyetçilik ve çelişik duygulu cinsiyetçilik kuramlarını temel alan Case, Hensley ve Anderson (2014) gerçekleştirdikleri müdahale çalışmasında farkındalık oluşturmak amacıyla iki deneysel koşul uygulamışlardır: erkeklere özgü ayrıcalıklar listesini okuma ve bununla ilgili değerlendirme yazısı yazma koşulu ve bu ayrıcalıklara ilişkin video izleme ve bununla ilgili değerlendirme yazısı yazma koşulu. Ayrıcalıklar listesinde, erkeklerin daha yüksek maaş alması, çocuk bakımında daha az rolü olması, daha az sosyal baskıya maruz kalması gibi avantajlar yer alırken; videoda da erkeklerin bu avantajlarının günlük yaşamdaki yansımalarına ilişkin paylaşımları yer almıştır. Bu koşulların, Çelişik Duygulu Cinsiyetçilik ve Modern Cinsiyetçilik ölçeklerinin yanı sıra, kendi geliştirdikleri soru formlarıyla erkeklerin sahip olduğu önceliklere dair farkındalık düzeyi ve önyargısız davranış için motivasyon düzeyi üzerindeki etkilerini incelemişlerdir. Sonuçlara göre, erkeklerin sahip olduğu ayrıcalıklara ilişkin farkındalık düzeyi yalnızca video izleme koşulunda artmış, ayrıcalıklar listesini okumanın böyle bir etkisi görülmemiştir. Benzer şekilde modern cinsiyetçilik düzeyinde de video izleme 
koşulunun azaltıcı etkisi görülürken, ayrıcalıklar listesini okuma koşulunda görülmemiştir. Ancak, düşmanca ve korumacı cinsiyetçilik düzeyleri ve önyargısız davranış için motivasyon düzeyi açısından her iki müdahale de başarılı olamamıştır. Araştırmacılar bu durumun, uygulanan müdahalenin içeriğinden kaynaklanabileceğini, korumacı ve düşmanca cinsiyetçilik düzeyini düşürmek için direkt olarak bu kavramları ve yaygın zararlarını içeren bir müdahalenin daha uygun olabileceğini belirtmişlerdir. Berryman (2020), korumacı cinsiyetçiliğin nüfuz eden yapısı ve tehlikelerini içeren bir metin okutarak katılımcılarının konuya ilişkin farkındalığını artırmayı amaçlamıştır. Ancak sonuçlara göre katılımcıların korumacı cinsiyetçiliği onaylama düzeylerinde anlamlı bir değişiklik görülmemiştir. Öte yandan, Good ve Woodzicka (2010) ise, genel bir müdahalenin korumacı cinsiyetçiliği onaylama eğilimini azaltmak hususunda yeterince etkili olmayacağını çünkü zaten korumacı cinsiyetçiliğin doğası gereği cinsiyetçilik olarak tanınmadığını belirtmişlerdir. Bu sebeple, özel olarak korumacı cinsiyetçiliği tanıtan ve sistematik zararlarını içeren bir metin okutmak suretiyle müdahale uygulamışlar ve altı ay süresince üç ölçüm alarak müdahalenin korumacı cinsiyetçiliği onaylama eğilimini azaltmayı başardığı sonucuna ulaşmışlardır. Bu sonucun sosyal istenirlik veya talep özelliklerinden kaynaklanmadığından emin olmak üzere gerçekleştirdikleri ikinci çalışmada, deney süresince alınan ölçümleri alakasız deneyler için alınan ölçümler gibi göstermek suretiyle bir sahte hikaye oluşturmuşlar ve geliştirdikleri müdahalenin başarısını onamışlardır.

Carrascosa, Cava Caballero, Buelga Vásquez ve Jesus (2019) ise, çevrim içi bir uygulama aracılığıyla uygulanan müdahalenin 12-17 yaş aralığındaki öğrencilerde çelişik duygulu cinsiyetçiliğin yanı sıra ilişkisel şiddet gibi değişkenlerdeki etkilerini incelemişlerdir. Müdahale olarak kullandıkları uygulama rol oynama, kağıt-kalem gibi çeşitli görevler içeren ve her bir oturumu bir saatten oluşan 12 saatlik bir programı içermektedir. Araştırmacıların ön-test ve son-test karşılaştırmalarına göre, müdahale grubunda düşmanca ve korumacı cinsiyetçilik düzeyinin düşmesinin yanı sıra incelenen tüm değişkenlerde anlamlı farklılaşmalar olduğu görülmüştür. Benzer şekilde, Navarro-Pérez, Oliver, Carbonell ve Schneider'1n (2020) çalışmasında da koruma kurumlarında çalışan 11-18 yaş aralığında çocuklarla çalışılarak eleştirel düşünmeyi destekleyen bir çevrim içi uygulama aracılığıyla müdahale uygulanmıştır. Sonuçlara göre müdahale hem düşmanca hem de korumacı cinsiyetçilik üzerinde azaltıcı bir etkiye sahiptir. Her iki araştırmada da özellikle genç yaş gruplarında müdahalenin önemi vurgulanarak benzer programların işlevsel olabileceği öne sürülmüştür. 
de Lemus, Navarro, Velásquez, Ryan ve Megías (2014), çelişik duygulu cinsiyetçilik kuramını temel alarak geliştirdikleri altı oturumluk müdahale programında sosyal inşa olarak toplumsal cinsiyet, kaynakların dağılımı ve sosyal zorunluluklar, ideoloji ve güç temalarını ele aldıkları interaktif tartışmalar gerçekleştirmiştir. Müdahale sonucunda katılımcıların düşmanca cinsiyetçilik düzeylerinin düştüğü, korumacı cinsiyetçilik düzeylerinin ise marjinal anlamlılık düzeyinde düştüğü görülmüştür. Benzer şekilde Kilmartin, Semelsberger, Dye, Boggs ve Kolar (2015), erkek üniversite öğrencilerinde çelişik duygulu cinsiyetçiliği ve tecavüzü destekleyici tutumları azaltmak üzere cinsiyetçi ifadelere maruz kalmanın etkilerini incelemişlerdir. Araştırmanın sonuçları, düşmanca ve korumacı cinsiyetçilik düzeylerinde marjinal anlamlılık düzeyinde bir azalmanın olduğunu ancak tecavüzü destekleyici tutumlarda bir değişim olmadığını göstermiştir. Araştırmacılar bu durumun korumacı cinsiyetçiliğin doğası gereği zor tanınıyor olmasından kaynaklanabileceğini tartışmışlardır.

Freedman, Seidman, Flanagan, Kaufman ve Green (2018) ise, geliştirdikleri bir mantık oyunu aracılığıyla "a-ha!" anını sağlayarak, bilim kadınlarına ilişkin olumsuz tutumları ve çelişik duygulu cinsiyetçiliği azaltmayı amaçlayan iki çalışma gerçekleştirmişlerdir. Katılımcılara sunulan mantık oyununun çözülebilmesi için oyunun hikayesinde geçen laboratuvarın yöneticisinin kadın olduğunun anlaşılması gerekmektedir. Katılımcıların \%90'ından fazlasının laboratuvar yöneticisinin erkek olduğunu varsayma eğiliminde olduğu görülmüştür. Araştırmacıların müdahalesi ise oldukça karmaşık sonuçlara yol açmıştır. İlk çalışmada müdahalenin cinsiyetçilik düzeylerinde herhangi bir etkisi olmamıştır. Katılımcıların oyundan ne kadar keyif aldıklarını da hesaba katarak gerçekleştirilen ikinci çalışmada ise, oyundan alınan keyif arttıkça bilim kadınlarına ilişkin olumlu tutumların da arttığı görülmüştür. Araştırmacılar bu bulguyu, oyundan alınan keyfin olası bir savunmacı yaklaşıma karşı tampon görevi gördüğü şeklinde yorumlamıştır. Ancak oyundan alınan keyfin çelişik duygulu cinsiyetçilik düzeyiyle olumlu yönde ilişkili olduğu görülmüştür. Ayrıca, ikinci çalışmada ise müdahalenin bilim kadınlarına karşı tutumları olumsuz yönde etkilediği ve çelişik duygulu cinsiyetçilik düzeyini de artırdığı görülmüştür. Araştırmacılar bu bulguyla cinsiyetçiliğe yönelik müdahale geliştirmenin zorluğuna dikkat çekerek; gerçekleştirdikleri müdahalenin örtük cinsiyet kalıp yargılarında etkilerinin bulunabileceğini ve hem açık hem de örtük ölçümlerin birlikte kullanılmasının gerekliliğini vurgulamışlardır.

Gündelik cinsiyetçilik kuramını temel alarak müdahale geliştirmeyi amaçlayan Cundiff, Zawadzki, Danube ve Shields'in (2014) araştırmasında ise deneyimsel öğrenme 
koşulu, grup aktivitesi koşulu ve yalnızca bilgi alma koşulu olmak üzere üç koşul uygulanmıştır. Shields, Zawadzki ve Johnson (2011) tarafından geliştirilmiş olan deneyimsel öğrenme koşulunda katılımcılar seçkisiz şekilde iki farklı takıma atanmış ve bir masa oyunu oynanmıştır. Oyun esnasında küçük ve zararsız görünen bazı farklılıklar yaratılmıştır (örn., bir başarının şansa/yeteneğe atfedilmesi). Oyunun ardından, katılımcıların deneyimlerini paylaştığı, araştırmacının ise oyunda temsil edilen durumun iş yaşamındaki kadın-erkek eşitsizliği olduğunu açıkladığı bir tartışma gerçekleştirilmiştir. Grup aktivitesi koşulunda da katılımcılar bir strateji oyunu oynamıştır ve ardından grup dinamikleriyle ilgili bir tartışma gerçekleştirilmiştir; ancak bu koşulda cinsiyete ilişkin herhangi bir ifade yer almamıştır. Yalnızca bilgi alma koşulunda ise, katılımcılara cinsiyete ilişkin dengesiz ve adil olmayan durumları içeren (örn., iş-aile dengesi) bir metin okutulmuştur. Araştırmacılar bu üç koşulun olağan cinsiyetçilik düzeyi ve cinsiyetçiliğe karşı davranışsal niyet düzeyi (örn., ayrımcılığın kaynağını araştırma, mekanizmasını anlamaya çalışma) üzerindeki etkilerini incelemişlerdir. Sonuçlara göre, deneyimsel öğrenme koşulunun diğer iki koşula göre olağan cinsiyetçilik düzeyini düşürmeyi ve cinsiyetçiliğe karşı davranışsal niyet geliştirmeyi artırdığı görülmüştür. Ayrıca, yalnızca bilgi verilmesi koşulunun da cinsiyetçiliğe karşı davranışsal niyet geliştirmeyi olumsuz yönde etkilediği görülmüştür. Araştırmacılar bu bulguya dikkat çekerek müdahale içeriğinin yanı sıra müdahalenin uygulanma şeklinin kritik rolünü vurgulamışlardır.

Örtük cinsiyet kalıp yargılarının gücünü azaltmayı hedefleyen Blair ve arkadaşları (2001), zihinsel imgelemenin etkilerini incelemişlerdir. Sonuçlara göre kalıp yargı karşıtı zihinsel imgeleme (güçlü kadın imgelemesi) örtük cinsiyet kalıp yargılarının zayıflamasını sağlamıştır. Bu çalışma, farkındalığın olduğu, niyetli bir süreç olan zihinsel imgelemenin, otomatik bir sürece tekabül eden örtük cinsiyet kalıp yargılarının gücünü etkilediğini göstermesi bakımından oldukça önemlidir. Başka bir deyişle, bazı araştırmacıların (örn., Wilson, Lindsey ve Schooler, 2000) ayrık mekanizmalar olarak değerlendirdiği örtük ve açık mekanizmaların etkileşimini göstermektedir. Benzer şekilde Ramos ve arkadaşları (2016), Glick ve Fiske'in (1996) Çelişik Duygulu Cinsiyetçilik Ölçeği'nde yer alan korumacı ve düşmanca cinsiyetçilik içeren ifadelere maruz kalmanın örtük cinsiyet kalıp yargıları üzerindeki etkilerini incelemişlerdir. Sonuçlar, yalnızca kadın katılımcılarda hem düşmanca hem de korumacı cinsiyetçi ifadelere maruz kalmanın örtük cinsiyet kalıp yargılarının gücünü zayıflattığını göstermiştir. Araştırmacılar bu sonucu, cinsiyetçiliğin mağduru olan grubun kadınlar olması nedeniyle motivasyonel 
farklılıklardan ve kadınların açık cinsiyet kalıp yargılarını reddetme eğiliminden kaynaklanabileceğini öne sürmüşlerdir. Bu araştırmanın sonuçları, kalıp yargı tehdidi alanyazınında yer alan, kalıp yargıların açık biçimde aktive edilmesinin performansı artırıcı etkisiyle de tutarlı görünmektedir (Gupta, Turban ve Bhawe, 2008; Kray, Thompson ve Galinsky, 2001).

Dasgupta ve Asgari (2004) ise, kadınların örtük cinsiyet kalıp yargıları üzerinde sosyal ortamın etkilerini bir laboratuvar çalışması ve bir de alan çalışması ile incelemişlerdir. Laboratuvar çalışmasının sonuçlarına göre, kadınların yargıç, lider, bilim insanı gibi geleneksel toplumsal cinsiyet kalıp yargılarıyla uyuşmayan rollerle yer aldığı fotoğraflarının veya biyografilerinin sunulması, kadınların örtük cinsiyet kalıp yargılarının gücünü azaltmanın yanı sıra, kalıp yargı karşııı örtük çağrışımlarının da güçlenmesine neden olmuştur. Alan çalışması kapsamında kadın üniversite öğrencilerinden bir yıl arayla aldıkları ölçümlerin sonuçları ise, örtük cinsiyet kalıp yargılarının gücünün kadın akademisyenden ders alma ile olumsuz, ancak erkek oranının daha fazla olduğu (male-dominated) dersleri alma ile olumlu yönde bir ilişkisi olduğunu göstermiştir. Böylece, laboratuvarda gözlenen, sosyal ortamın örtük cinsiyet kalıp yargıları üzerindeki etkisi, yüksek ekolojik geçerlilikle de onanmıştır.

Tinkler, Li ve Mollborn (2007), yasal dayanaklı bir müdahalenin hem örtük hem de açık cinsiyetçilik üzerindeki etkilerini araştırmak üzere üniversitenin cinsel şiddete ilişkin politikasını okuma ve buna ek olarak deneyde yer alan bir görevde erkeklerin daha başarılı olduğuna dair enformasyon alma koşullarının, Cinsiyete Dayalı Semantik Farklılaşma Ölçeği (üç boyut: statü, yeterlilik ve saygınlık) ve örtük cinsiyet kalıp yargıları üzerindeki etkilerini incelemişlerdir. Sonuçlara göre, üniversitenin cinsel şiddete ilişkin politikasını okumak katılımcıların örtük cinsiyet kalıp yargılarının gücünü artırmıştır. Araştırmacılar bu bulgunun, metnin kalıp yargı aktivasyonuna neden olmasından kaynaklanabileceğini öne sürmüşlerdir. Nitekim, deneyde yer alan görevde erkeklerin daha başarılı olduğu enformasyonunun sunulduğu koşulda böyle bir etki görülmemiş ve araştırmacılar bu durumu açık şekilde cinsiyet kalıp yargılarının aktive edilmesinin bir çeşit ters tepkiye (backlash effect) yol açtı̆̆ şeklinde tartışmışlardır. Açık cinsiyet kalıp yargılarında ise herhangi bir farklılaşma görülmemiştir. Bu noktada, araştırmacılar tutumun ikili yapısının önemini vurgulamış, açık ve örtük tutumların farklılaşabileceğine ve bu iki formun birlikte incelenmesi gerektiğine dikkat çekmişlerdir.

Örtük cinsiyet kalıp yargılarının değişkenliğini 13 çalışmayı kapsayan bir meta-analizle inceleyen Lenton ve arkadaşları (2009) örtük cinsiyet kalıp yargılarının değişime 
açık olduğu sonucuna ulaşmış, ancak etki büyüklüğünün düşük olduğunu belirtmişlerdir. Müdahale çalışmalarının etkililiğini belirleyen değişkenler ise müdahale tipi, örneklemin milliyeti ve yayın statüsüdür. Müdahale tiplerinden cinsiyet kalıp yargılarını baskılamaya çalışmanın örtük cinsiyet kalıp yargılarının gücünü düşüremediği görülmüştür. Bunun yerine, bir sosyal kategoriyi değerlendirirken farklı ölçütler yaratmanın veya kalıp yargı karşıtı aktivasyon gerçekleştirmenin örtük cinsiyet kalıp yargılarının gücünü azaltmada etkili bir müdahale olduğu görülmüştür. Örneklemin milliyeti açısından ise Amerika örnekleminde yapılan müdahale çalışmalarının daha yüksek etki güçleri elde ettiği görülmüştür. Araştırmacılar bu durumu, örtük cinsiyet kalıp yargılarının kültüre göre farklılaşabileceği ve bu nedenle Amerika örnekleminde geliştirilmiş Örtük Çağrışım testi ve müdahalelerin diğer örneklemlerde aynı etkiyi göstermeyebileceği şeklinde açıklamıştır. Son olarak, yayın statüsü müdahale etkililiğinde en güçlü yordayıcıdır. Araştırmacılar, müdahalelerin etkililiğinin sanılanın aksine daha düşük olabileceğini, sadece yayımlanan araştırmaların sonuçlarını değerlendirmenin müdahalelerin başarısının abartılı düzeyde algılanmasına neden olabileceğini öne sürmüşlerdir. Ayrıca bu durum müdahale çalışmalarının sonuçlarının belirgin ve tutarlı bir müdahale içeriğine veya yöntemine işaret edememesinin olası bir nedeni olarak da değerlendirilebilir.

Davranış düzeyinde cinsiyetçiliği azaltmayı hedefleyen Kawakami ve arkadaşlarının (2007) müdahalesi ise ilginç bir öneri sunmaktadır. Araştırmacılar, kalıp yargıların aktivasyon ve uygulama olmak üzere iki farklı aşama içerdiğini vurgulayarak, kalıp yargıların her zaman davranışı belirlemeyeceğini, bir düzeltme aşamasının olabileceğini göstermiştir. Araştırmada kalıp yargı karşıtı çağrışımlar sağlayan bir eğitimin ardından, katılımcılara iki aşamalı bir işe alım görevi verilmiştir. Bir aşama her bir adayın belirli özellikler çerçevesinde değerlendirilmesinden, diğer aşama ise adaylar arasında tek bir adayın seçilmesinden oluşmaktadır ve bu aşamaların sırası katılımcılar arasında ABBA yöntemi ile dengelenmiştir. Araştırmanın sonuçları, verilen kalıp yargı karşıtı eğitimin olumlu etkilerinin görüldüğünü, ancak burada işe alım görevindeki aşamaların nasıl sıralandığının kritik bir rolü olduğunu göstermektedir. Tek bir aday seçme aşamasının ikinci görev olduğu koşulda, ilk görev olduğu koşula göre kadın aday seçme olasılığının daha yüksek olduğu görülmüştür. Yani, katılımc1lar görevin üzerinde düşünme ve detayl1 bilişsel işlem için gerekli zamana sahip olduğunda geleneksel toplumsal cinsiyet kalıp yargılarının etkisi ortadan kalkmıştır.

Eğitim alanında, özellikle anaokulu ve ilkokul düzeyindeki eğitim ortamında cinsiyetçiliğe yönelik müdahale çalışmalarının önemi ve gerekliliği vurgulansa da bu konuda 
yapılan çalışmalar henüz oldukça az sayıdadır (Liben ve Coyle, 2014; Meyer, 2008). Lundeberg'in (1997) öğretmen adaylarıyla yaptı̆̆ araştırmada, cinsiyetçilikle ilgili bilgiler içeren ve adayların fikirlerinin ve deneyimlerinin paylaşıldığı grup tartışmasının cinsiyetçiliğe ilişkin farkındalığı artırdığı görülmüştür. Bravo, Gilbert ve Kearney (2003) ise, teknoloji sınıfında cinsiyet eşitliğini sağlayabilmek adına skeçlerden faydalanmışlardır. Ergenlerin çeşitli roller aldıkları ve tartıştıkları aktiviteler düzenlemişler ve görüşmelerle elde ettikleri bilgiler sonucunda hem öğretmenlerin hem de öğrencilerin teknolojiye ilişkin cinsiyet kalıp yargılarının gücünün azaldığını belirtmişlerdir. Hong, Lin ve Veach'in (2008), 12-14 yaş ergenlerde 13 hafta süren ve bilimsel performans, benlik değeri gibi konuları içeren ve her bir konu bağlamında cinsiyet eşitliğinin de vurgulandığı müdahale çalışmasının sonucunda, görüşmelerden elde edilen bilgiler cinsiyetçilik düzeyinin düştüğüne işaret etse de niceliksel analizlerde böyle bir bulguya ulaşılamamıştır.

Lamb, Bigler, Liben ve Green (2009), ilkokul öğrencileriyle gerçekleştirdiği müdahale çalışmasında ise pratik koşulu ve öykü koşulu olmak üzere iki koşul kullanmıştır. Pratik koşulunda, çocuklara akranlarının cinsiyetçi ifadelerine tepki vermeleri öğretilmiş ve pratik yaptırılmıştır (örn., "Bu oyunu sadece erkekler oynar.” cümlesine karşıllık "Hayır, cinsiyet insanları kısıtlayamaz!” yanıtı vermek). Öykü koşulunda ise, akranlarının cinsiyetçi ifadelerine tepki veren bir çocuğu anlatan öykü dinletilmiş, tekrar veya pratik yaptırılmamıştır. Araştırmacılar, bu koşulların, sözde bir durumda çocukların akranlarının cinsiyetçi tutumlarına karşı tepkileri, kendilerini ve diğerlerini ne kadar kadınsı/erkeksi tanımladıkları ve cinsiyet kimlikleri (örn., cinsiyet kalıp yargılarına uygun davranma yönünde baskı hissetme, hemcins lehine yanlılık gibi) üzerindeki etkilerini hem müdahaleden hemen sonra hem de altı ay sonra incelemişlerdir. Sonuçlar, pratik koşulunun öykü koşuluna göre daha başarılı bir müdahale sağladığını göstermiştir. Pratik koşulunda yer alan çocukların sözde bir durumda akranlarının cinsiyetçi tutumlarına karşı tepki verme düzeyleri daha yüksektir ve bu etki altı ay süresince devam etmiştir. Diğer bağımlı ölçümlerde ise müdahale etkileri görülmemiş veya çok zayıf düzeyde görülmüştür. Araştırmacılar, çocuklarda pek çok konuda olduğu gibi cinsiyet kalıp yargıları konusunda çalışırken de pratik ile öğrenmenin önemini vurgulamışlardır.

Hilliard ve Liben'in (2010) araştırmasında ise çocuklarda cinsiyetçilik düzeyinin artmasını tetikleyen nedenleri incelenmiştir. Cinsiyetin sınıf ortamında görünür kılınmasının (örn., cinsiyete göre farklı sıralar oluşturmak) 3-5 yaş aralığındaki çocuklarda 
cinsiyet kalıp yargılarının gücünü artırdığg görülmüştür. Cinsiyet görünürlüğünün artması, çocukların diğer cinsiyetten akranlarına karşı daha az olumlu değerlendirmelerde bulunması ve diğer cinsiyetten akranlarıyla daha az birlikte oynamasına yol açmıştır. Araştırmacılar, çocuğun içinde en uzun süreler bulunduğu sosyal ortamlardan biri olan sınıftaki düzenlemelerin etkilerini göstererek özellikle eğitim ve meslek seçimi gibi konularda özelleştirilmiş müdahale çalışmalarının eksikliğini tartışmışlardır.

Cinsiyetçiliği azaltmayı hedefleyen araştırmalarda, müdahale programlarının işlevlerinin sosyal bağlamlara, gruplara göre farklılaşması doğal ve kaçınılmaz olmakla birlikte, müdahalelerin etkililiğinin anlaşılabilmesi için bu farklılaşmaların da ortaya konması, hangi yöntemlerin hangi cinsiyetçilik türlerinde etkili olabileceği hususunda bir uzlaşıya varılması önemlidir. Bu noktada, henüz çelişkili bulgular olduğu görülmektedir. Kanımızca, bu durum cinsiyet kalıp yargılarının çok karmaşık temelleri olması, çok erken yaşlarda oluşması ve diğerine ilişkin izlenim oluşturma aşamasında ilk algılanan fiziksel özelliklerden biri olması nedenlerinden kaynaklanıyor olabilir. Öte yandan, başarılı olmuş müdahale tiplerinin geliştirilmesi, kültürlerarası geçerliliğinin sınanması ve yaygınlaşması hem bireysel hem de toplumsal açıdan uygun düzenlemelerin gerçekleştirilmesi için kritik önem taşımaktadır.

\section{Farkındalığın Etkileri}

Cinsiyetçiliği azaltmaya ilişkin müdahale çalışmalarında dikkat çeken unsurlardan biri farkındalıktır. Erkekler, başkalarının cinsiyetçilik düzeylerini olduğundan fazla ve kendi cinsiyetçilik düzeylerini ise olduğundan az gibi algılamaktadır. Sadece bu farkındalığ1 yaratmanın bile cinsiyetçiliği azaltmada etkili olduğu görülmüştür (Kilmartin ve ark., 2008). İnsanların örtük ve açık cinsiyetçilik düzeylerinin de ilişkili olmadı̆̆ 1 veya düşük düzeyde ilişkili olduğu bilinmektedir (Bargh ve ark., 1996; Blair ve Banaji, 1996). Bir başka deyişle, insanlar sahip oldukları cinsiyetçi tutumların farkında olmayabilirler. Sadece farkındalık kazanmanın bile (özellikle korumacı) cinsiyetçilik üzerinde azaltıcı etkisi görülmüştür (Case ve ark., 2014; Good ve Woodzicka, 2010). Nitekim kalıp yargı tehdidini inceleyen araştırmalarda da farkındalığın düzenleyici rolü olduğu görülmüştür (Gupta ve ark., 2008; Kray ve ark., 2001).

Benzer şekilde, Parker, Monteith, Moss-Racusin ve Van Camp (2018), insanlara sahip oldukları cinsiyet yanlılıklarına dair kanıt sunmanın ve kanıta dayanmadan yalnızca cinsiyet yanlılıklarına ilişkin bilgilendirmenin hangi duygulara neden olduğunu ve katı- 
lımcıların gelecekteki olası cinsiyet yanlılıklarını kontrol etme niyetleri üzerindeki etkilerini incelemişlerdir. Sonuçlar, katılımcıların kendi cinsiyet yanlılıklarına dair kanıt (katılımcının sonuçlarının diğer katılımcılara göre daha fazla cinsiyet yanlılı̆̆ içerdiği yönünde sahte bir enformasyon) sunmanın, suçluluk gibi benliğe yönelik olumsuz duygulara neden olduğunu ve bu durumun gelecekte cinsiyet yanlıllğını azaltmaya ilişkin davranışsal niyetlerin artmasına aracılık ettiğini göstermiştir. Kanıta dayanmaksızın cinsiyet yanlılıklarına ilişkin bilgilendirmenin ise benliğe yönelik olumsuz duyguların ve gelecekte cinsiyet yanlılığını azaltmaya ilişkin davranışsal niyetin daha düşük düzeyde olmasına neden olduğu görülmüştür. Araştırmacılar, bu sonuçların farkındalığın rolünü vurguladığını, özellikle işe alım gibi görevleri olan insanların bu konuda eğitime tabi tutulması gerektiğini ve geliştirilecek müdahale çalışmalarında da farkındalık yaratmak için kanıtlardan faydalanmanın kritik düzeyde önemli olduğunu öne sürmüşlerdir.

Öte yandan cinsiyet kalıp yargılarının görünürlüğünü artırmanın örtük cinsiyet kalıp yargılarının gücünü de artırmak yönünde etkileri görülmektedir (Tinkler ve ark., 2007). Örtük kalıp yargıların ayrımcı davranışları yordadığı bilgisi de göz önüne alınarak (Bkz. Greenwald, Banaji ve Nosek, 2015), gelecek çalışmalarda geliştirilecek müdahalenin örtük yapı üzerindeki etkilerinin incelenmesi ve olası bir olumsuz etkinin önlenmesi gerekmektedir. Bu noktada farkındalıkla birlikte toplumsal cinsiyet kalıp yargıları karşıt1 aktivasyonun birlikte kullanılması faydalı olabilir.

\section{Cinsiyetçiliğe Müdahale Çalışmalarında Yöntemsel Sorunlar}

Müdahale çalışmalarında içerikle birlikte kullanılan yöntemin de oldukça önemli olduğu görülmektedir. Konuya ilişkin video izleme, pratik yapma, mikro-saldırganlığ 1 deneyimleme, kalıp yargı karşıtı imgeleme gibi yöntemlerin, sadece okuma veya dinlemeye göre cinsiyetçiliği azaltmada daha etkili olduğu görülmüştür (Blair ve ark. 2001, Case ve ark., 2014; Cundiff ve ark., 2014; Lamb ve ark., 2009). Bu yöntemler, katılımcıların müdahale sürecine daha çok dahil oldukları, süreçle daha fazla ilişkilendikleri yöntemler olarak değerlendirilebilir.

Müdahale çalışmalarında cinsiyetçiliğin hangi formunun veya formlarının azaltılmaya çalışıldığı da sonuçları değerlendirirken kritik bir öneme sahiptir. Bu nedenle pek çok araştırmacı cinsiyetçiliğin farklı formlarının bir arada kullanılması gerekliliğine dikkat çekmiştir (örn., Freedman ve ark., 2018; Tinkler ve ark., 2007).

Talep Özellikleri. Açık ve gizil formlarda cinsiyetçiliği değiştirmeyi hedefleyen 
müdahale çalışmalarının büyük bir kısmında öntest-sontest ölçümlerinin uygulandığ görülmektedir (örn., Cundiff ve ark., 2014; de Lemus ve ark., 2014). Böyle bir desende kaçınılmaz olan talep özellikleri (demand characteristics) sorunu devreye girmekte ve sonuçların güvenilirliğini etkilemektedir. Elde edilen sonuçların katılımcıların araştırmanın amacını anlaması ile ilişkili olma ihtimali önemli bir alternatif hipotez olarak belirmektedir. Talep özellikleri sorununu aşmaya yönelik iyi bir örnek Good ve Woodzicka'nın (2010) araştırmasıdır. Araştırmacılar deney süresince aldıkları ölçümleri farklı araştırmaların parçaları olarak göstererek yarattıkları sahte hikaye ile elde ettikleri sonuçlarda talep özelliklerinin etkisini bertaraf etmişlerdir. Cinsiyetçiliğe ilişkin bir ölçeği bir kez doldurmanın bile cinsiyet kalıp yargılarının zihinde aktive olmasına, hazırlama etkisi yaratmasına olanak sağlayabileceği göz önünde bulundurulduğunda, gelecek çalışmaların araştırma desenlerinde talep özelliklerinin bertaraf edilmesi oldukça önemli görünmektedir.

Ekolojik Geçerlilik. Müdahale çalışmalarında ekolojik geçerlilik konusu daha da önem kazanmaktadır. Çünkü gerçek yaşamda temsil edilebilirlik müdahalenin esas hedeflerindendir. Tutumlar çoğu zaman davranışı güçlü şekilde yordasa da (Armitage ve Conner, 2001) düşmanca cinsiyetçilik gibi sosyal istenirliğin devreye girdiği konularda tutumun davranışı yordama gücü düşmektedir (de Oliveira Laux, Ksenofontov ve Becker, 2015; Duehr ve Bono, 2006). Ancak müdahale çalışmalarında davranışsal çıktıları hedefleyen çalışmaların sayısı oldukça azdır. Örneğin Kawakami ve arkadaşlarının (2007) araştırma sonuçları, uygulanan müdahalenin etkilerinin gözlenmesinin katılımc1ların işe alım görevini tamamlamak üzere detaylı düşünmek için zamanının olmasına bağlı olduğunu göstermiştir. Yeterli zaman olması durumunda katılımcıların kararlarında geleneksel cinsiyet kalıp yargılarının etkisinin azaldığı görülmüştür. Bu husus cinsiyetçi tutumların davranışa dönüşmesi sürecinde kritik bir role sahip olabilir. Başka bir deyişle, açık, gizil veya örtük cinsiyetçiliğin davranışa dönüştüğü sürece ilişkin mekanizmanın henüz yeterince incelenmediği ve tam anlamıyla anlaşılmadığı görülmektedir. Oysa cinsiyet kalıp yargılarının çıktıları olarak cinsiyetçi davranışı önlemek açısından söz konusu aracı mekanizmalar büyük önem taşımaktadır.

Sürdürülebilirlik. Müdahale çalışmalarında önemsenmesi gereken bir başka mesele de müdahale etkilerinin ne kadar sürdürülebilir olduğudur. İlkokul ders kitaplarından kitle iletişim araçlarına dek pek çok uyaranın toplumsal cinsiyet kalıp yargılarını beslediği bir sistemde (Bkz. Kılıç, Beyazova, Akbaş, Zara ve Serhatlı, 2014; Mora, 2006) 
müdahale etkisinin zaman içinde takip edilmesi oldukça önemlidir. Ancak çok az araştırmada müdahale etkileri uzun süreli olarak takip edilmiştir. Örneğin Lamb ve arkadaşlarının (2009) çalışmasında cinsiyet kalıp yargıları karşıtı davranışlar içeren bir öykü dinlemek ve cinsiyet ları karşıtı davranışları pratik etmek şeklinde iki tür müdahale uygulanmış ve gözlenen etkiler hem müdahale sonrasında hem de müdahaleden altı ay sonra izlenerek etkilerin sürdürülebilirliği onanmış ve gözlenen değişimler incelenmiştir. Bu gözlem önemli bilgiler sağlamıştır: öykü koşulunda bulunan çocuklarda altı ay sonra uygulanan testte müdahaleden hemen sonra uygulanan teste göre cinsiyetçi tutumlara karşı çıkmanın daha da arttığı şeklinde bir bulgu elde etmişılerdir. Öte yandan, pratik koşulunda yer alan çocukların cinsiyetçi tutumlara karşı çıkma oranı her iki ölçümde de daha yüksektir. Araştırmacılar bu bulguyu, akranların birbirleriyle etkileşimlerinin müdahale etkisinden daha güçlü olabileceği ihtimaliyle tartışmışlar, yeni ve oldukça kullanışlı bir araştırma sorusu öne sürmüşlerdir.

\section{Müdahale Çalışmalarında Hangi Cinsiyetçilik Hedeflenmeli?}

Müdahale çalışmalarında açık ölçümlerin (örn., Bem Cinsiyet Rolü Envanteri) kullanılmaması; yerine gizil (örn., Çelişik Duygulu Cinsiyetçilik Ölçeği) veya örtük ölçümlerin (örn., Örtük Çağrışım Testi) kullanılması hem sosyal istenirlik hem de talep özellikleri gibi önemli karıştırıcılık potansiyeli olan unsurların bertaraf edilmesi açısından oldukça önemlidir. Ancak genel olarak, müdahale çalışmalarının açık veya gizil cinsiyetçiliği azaltmak konusunda uzlaşıya varamadığı, elde edilen sonuçların oldukça çelişkili olduğu görülmektedir. Özellikle, cinsiyetçilik karşıtı eğitim vermek veya metin okutmak gibi yöntemler çoğu zaman başarılı olamamış veya kısmen başarılı olmuştur (örn., Case ve ark., 2014; de Lemus ve ark., 2014). Öte yandan kalıp yargı karşıtı imgeleme/aktivasyon gerçekleştirmenin örtük cinsiyetçilikte nispeten tutarlı bir müdahale başarısı sağladığı görülmüştür (örn., Blair ve ark., 2001; Dasgupta ve Asgari, 2004). Bu bulgulardan hareketle, direkt açık veya gizil cinsiyetçilik formlarına müdahalenin, en azından bugünkü bildiklerimizle yeterince etkili sonuçlara ulaşamadığı; bunun yerine örtük cinsiyet kalıp yargıları, SKÖÇ gibi cinsiyetçiliğin tutum veya davranışa dönüşmesine aracılık eden yapıları hedefleyen müdahale çalışmaları daha gerçekçi ve işlevsel olabilir.

\section{Cinsiyetçiliği Azaltmaya Yönelik Müdahale Programları İçin Bir Sınıflandırma Önerisi}

Cinsiyetçiliğe ve toplumsal cinsiyet önyargılarına müdahale çalışmaları gözden geçirildiğinde göze çarpan en önemli olgunun müdahalenin etki gücünün zayıflığı (örn., 
Case ve ark., 2014) ya da etkisizliği (örn., Kilmartin ve ark., 2015), hatta istenmeyen yönde etki göstermesi (Freedman ve ark., 2018) noktasında bulguların tutarsızlığı dikkat çekmektedir. Toplumsal cinsiyete ilişkin kategorilerin çok erken yaşlarda oluşması (örn., Hill ve Flom, 2007), cinsiyetin tespitinin evrimsel açıdan önemli ve üreme başarıs1 üzerinde etkili oluşu (örn., Rosenthal, 2017), cinsiyet kategorizasyonunun diğer grup oluşumlarına göre (örn., 1rk vb.) daha güçlü ve otomatik bir biçimde kodlanması (Kurzban, Tooby ve Cosmides, 2001) gibi unsurlar toplumsal cinsiyet kalıp yargılarının değişime direncini açıklayabilir. Bununla birlikte, cinsiyetçi önyargıların hafifletilmesi açısından umut verici çalışmalar da mevcuttur (Dasgupta ve Asgari, 2004). Etkili müdahalenin mümkün olduğunu gösteren çalışmaların ortak noktalarından biri, müdahalenin odak noktasının cinsiyetçi tutumlardan ziyade aracı (mediator) bilişsel yapılara yönelmesidir (örn., Blair ve ark., 2001). Cinsiyete ya da toplumsal cinsiyete ilişkin bir bilgi taşıyan uyaranın algılanmasıyla, bu uyaranın cinsiyetçi bir tepkiye dönüştürülmesine aracılık eden bazı bilişsel yapıların olduğunu varsaymak akla yatkın görünmektedir. Bunlar toplumsal cinsiyet kalıp yargıları, toplumsal cinsiyete bağlı kişilik özelliği çıkarımları yapma eğilimleri, toplumsal cinsiyet şemaları, toplumsal cinsiyete ilişkin örtük varsayımlar vb. zihinsel yapılar olarak düşünülebilir. Bu aracı yapılar tek tek veya bir arada çeşitli etkiler oluşturarak cinsiyetçi tutumlara ve nihayetinde cinsiyet ayrımcılığı içeren davranışlara aracılık ediyor olabilirler. Toplumsal cinsiyet önyargılarına müdahale etmeyi hedefleyen çalışmaların çoğu nihai ürünü, yani cinsiyetçi tutumları değiştirmeyi hedeflediği için başarısızlıkla sonuçlanıyor olabilir. Çünkü cinsiyetçi tutum ve davranışların değişmesi çoğu zaman onları hazırlayan diğer psikolojik yapıların değişmesine bağlıdır. Kişinin cinsiyet bilgisi taşıyan bir uyaranı nasıl algılayacağı, bu uyaranı hangi kişilik özellikleriyle ilişkilendireceği ve ne gibi çıkarımlar yapacağı değiştirilmeden cinsiyetçi tutumlara müdahale etmeye çalışmak gerçekçi gözükmemektedir. Bu çalışmada yapılacak kavramsallaştırmaya göre cinsiyetçilik olgusu, cinsiyet bilgisi taşıyan herhangi bir uyaranın algılayıcı tarafından kaydedilmesi süreci ile tetiklenmektedir. Dolayısıyla sözü edilen aracı yapıları yeterince dikkate almayan müdahale programları da başarılı olamayacaktır. Bu nedenlerle, cinsiyetçiliğe yönelik müdahale programları için dört aşamadan oluşan bir sınıflandırma önerilerek, her bir aşamada gerçekleştirilen çalışmalardan örnekler verilecek ve gelecek araştırmalar için bazı önerilerde bulunulacaktır: (1) cinsiyet belirten bir uyaranın algılanması sürecine müdahale, (2) cinsiyet bilgisinin (örtük veya açık bir şekilde) kişilik özellikleriyle (veya rollerle) ilişkilendirilmesi sürecine müdahale, (3) (açık, gizil veya örtük) cinsiyetçi tutumlara müdahale ve (4) cinsiyetçi davranışlara müdahale (Bkz. Şekil 1). 


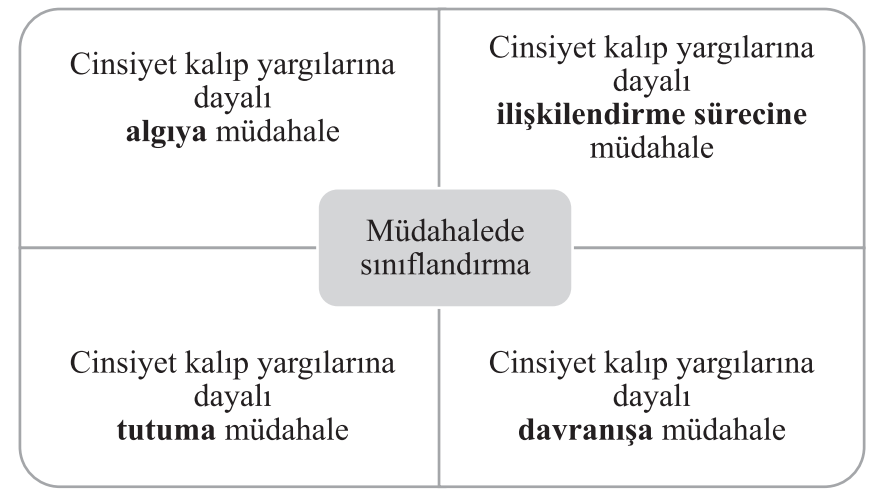

Şekil 1. Cinsiyetçiliğe müdahale araştırmalarına yönelik sinıflandırma önerisi

Cinsiyet Belirten Bir Uyaranın Algılanması Sürecine Müdahale. Bireyin diğerine ilişkin cinsiyet bilgisi içeren herhangi bir enformasyona maruz kalması ve algılaması esnasında cinsiyet kalıp yargılarının etkileri görülmektedir; cinsiyet kalıp yargıları ile uyumlu enformasyon daha sağlam şekilde kaydedilmektedir (Newall ve ark., 2018; Proverbio, Alberio ve De Bendetto, 2018). Edinilen yeni enformasyonun kodlandığ olarak ifade edilen SKÖÇ’ün aktivasyon aşamasında da cinsiyet kalıp yargılarının benzer etkileri görülmektedir. Bir başka ifadeyle, cinsiyet kalıp yargılarıyla uyumlu enformasyon, uyumsuz enformasyona göre daha güçlü çıkarımlara neden olmaktadır (Yan ve ark., 2012). Sosyal alg1 alanyazınından, yukarıdan aşağıya bilgi işlemenin, yani zihindeki mevcut kategorilere dayanarak işlemleme yapmanın, yeni karşılaşılan bir uyaranın algılanışını etkilediğini hem davranışsal yöntemler hem de beyin görüntüleme ile elde edilen bulgular göstermiştir (örn., Hugenberg ve Bodenhausen, 2004; Proverbio ve ark., 2017). Ancak, cinsiyet bilgisi taşıyan bir uyaran özelinde, bu uyaranın algılanma veya kodlanma aşamalarını göz önünde bulunduran ve bunun tepkileri düzenleyebilecek olas1 etkilerini hedefleyen bir müdahale çalışmasına rastlanmamıştır. Bu durum söz konusu aşamalara müdahalenin nispeten zor olmasından kaynaklanıyor olabilir. Oysa bu aşamada cinsiyet kalıp yargılarına dayalı yanlılığın azaltılması verili sonuçlardan çok daha kalıcı ve güçlü müdahale etkilerine zemin hazırlama potansiyelinden dolayı oldukça önemlidir. Nitekim cinsiyetçi tutumlara yönelik farkındalık yaratılmasının müdahalede kısmen olumlu etkileri olduğundan daha önce bahsedilmiştir. Cinsiyetle ilgili bir uyaranın kalıp yargısal bir işlemlemeye tutulduğunun farkına varılmasının, yani kişiye kalıp yargılara dayalı düşündüğünün fark ettirilmesinin de benzer bir etkiye yol açabileceğini 
düşünmek mümkündür. Sürecin sosyal algıya dayalı bu erken basamağına müdahale etmenin özellikle genç yaşlardaki bireylerin katı cinsiyetçi tutumlar geliştirmesinin önüne geçmede etkili olabileceğini düşünmek akla yatkın gelmektedir. Nitekim göreceli olarak daha erken yaşlardaki bireylerin tutum değişimine daha açık olduğu, buna karşılık yaş ilerledikçe tutumların daha kararlı ve değişime dirençli hale geldiği bilinmektedir (Koenig, McGue ve Iacono, 2008; Krosnick ve Alwin, 1989).

\section{Cinsiyet Bilgisinin Kişilik Özellikleriyle İlişkilendirilmesi Sürecine Müdahale.}

İnsanların zihinlerindeki kalıp yargılar ile uyumlu bilgilere daha fazla dikkat gösterdiği ve muhtemelen bunun sonucu olarak da kalıp yargılarına uygun örnekleri daha iyi hatırladıkları bilinmektedir (Berthold, Steffens ve Mummendey, 2019; Huang ve Sherman, 2018). Bu durum, kalıp yargıların gerçeği yansıtmayan ilişkiler kurma eğilimlerinin ürünü olsa bile (örn., sahte korelasyon) onların güçlenmesine ve kişiler tarafından daha inanılır görülmesine yol açan bir etki yaratmaktadır. Örneğin 'kadınlar konuşkandır' kalıp yargısı görgül olarak doğru olmamasına rağmen birçok insan tarafindan kabul görmektedir (Mehl, Vazire, Ramírez-Esparza, Slatcher ve Pennebaker, 2007). Eğer her konuşkan kadın daha çok dikkat çekiyor ve daha sonra da daha iyi hatırlanıyorsa, öte yandan az konuşan kadın daha az dikkat çekiyor ve daha az hatırlanıyorsa konuşkanlık özelliğini kadın kategorisi ile ilişkilendirme eğilimi güçlenecektir. SKÖÇ’ün uzun süreli bellekteki yansımasını ifade eden ilişkilendirme aşamasında da çıkarsanan kişilik özelliği kalıp yargısal olarak kadınsı bir özellikse (örn., gevezelik) gözlenen aktörün kadın olması durumunda gerçekleşen çıkarımlar güçlenmektedir (Soylu, 2017). Ekolojik geçerliliği Örtük Çağrışım Testi’ne kıyasla daha yüksek olan ve yine sosyal istenirlik ve talep özellikleri unsurlarından etkilenmeyen SKÖÇ’ün, cinsiyetçiliğin tutuma ve davranışa dönüşmesinde bir basamak olarak incelenmesi faydalı olacaktır. Özellikle ilişkilendirme aşaması cinsiyetçiliğe zemin hazırlayan bir sosyal bilişsel yapıya tekabül edebilir. Çünkü gerçek yaşamda meydana gelen davranışlar ve verilen kararlar SKÖÇ’ün (uzun süreli belleğin de devreye girdiği) ilişkilendirme aşamasından etkileniyor olabilir. $\mathrm{Bu}$ çıkarımlar tutumlara zemin hazırlayan yapılar olarak ele alındığında cinsiyetçiliğin azaltılmasındaki kritik rolü açıktır. Direkt olarak tutumlar üzerinde cinsiyetçiliğin etkilerini azaltma girişimlerindense, aracılık edebilecek mekanizmaların hedeflenmesi alanyazındaki çelişkili bulguların netlik kazanmasını sağlayabilir.

Cinsiyetçi Tutumlara Müdahale. Yapılan müdahale çalışmalarının büyük bir çoğunluğu cinsiyetçi tutumları hedeflemektedir. Ancak yukarıda da bahsedildiği gibi bul- 
gular henüz net bir çözüm önerisi sunamamaktadır. $\mathrm{Bu}$ evreye müdahale etmeyi amaçlayan araştırmalarda iki temel sorun göze çarpmaktadır. Tutumların açık, gizil ve örtük şeklinde farklı formlarda bulunması ve aynı formdaki cinsiyetçi tutumların farklı biçimlerde ölçülmesi alanyazının uzlaşıya varamamasının sebeplerinden bazıları olabilir. Cinsiyetçi tutumların ölçümünde hem açık ve gizil hem de örtük tutumların birlikte incelenmesi oldukça önemlidir; aksi takdirde gerçekleştirilen müdahalenin sonuçları tam anlamıyla gözlenemez. Nitekim Tinkler ve arkadaşlarının (2007) araştırmasında, müdahalenin açık tutumlarda etkisiz olduğu, örtük tutumlarda ise istenmedik yönde etki gösterdiği görülmüştür. Benzer örüntülerin pek çok müdahale sonucunda gözlenmesi muhtemeldir, ancak pek çok araştırmada tutumun çok boyutlu yapisı vurgulansa da çoklu ölçüm alınmamıştır (örn., Freedman ve ark. 2018). Göze çarpan ikinci sorun ile ilgili ise güncel yapıyı gözlemede en uygun olarak nitelendirilebilecek gizil cinsiyetçilik formu olarak çelişik duygulu cinsiyetçilik (Glick ve Fiske, 1996) ve modern cinsiyetçilik kuramlarından (Swim ve ark. 1995) hareketle müdahale geliştirmek ve önerilen ölçümleri dahil etmek alanyazının tutarlı bulgular sunması açısından yerinde olacaktır. Örtük cinsiyetçi tutumlarda ise düşük etki gücünde olmakla birlikte nispeten tutarlı bulgular mevcuttur ve pek çok araştırmada aynı yöntemin (Örtük Çağrışım testi) versiyonları kullanılmıştır (Bkz. Lenton ve ark., 2009). Kişilerin zihinlerindeki kalıp yargılar ile uyuşmayan örneklere maruz bırakılması yani normalde dikkat etmeyecekleri ve hatırlamayacakları uyaranlara dikkat etmeye yönlendirilmeleri cinsiyetçiliğin bu evresine yönelik gerçekleştirilen uygun müdahale örneklerinden biri olabilir. Nitekim Dasgupta ve Asgari (2004), katılımcılara toplumsal cinsiyet kalıp yargılarıyla uyuşmayan örnekler göstermek yoluyla örtük cinsiyet kalıp yargılarını değiştirmeyi başarmıştır.

Cinsiyetçi Davranışlara Müdahale. Tutumlar her ne kadar davranışın belirleyicisi olarak ele alınsa da tutum-davranış ilişkisindeki aracı değişkenler henüz tam anlamıyla saptanabilmiş değildir (Bkz. Armitage ve Christian, 2003; McConnell ve Leibold, 2001). Bu nedenle davranış evresi yukarıda bahsi geçen üç evrenin bir çıktısı olmakla birlikte, direkt bu evreyi hedefleyen müdahale çalışmaları da oldukça önemlidir. Ancak, alanyazında cinsiyetçiliğin davranışsal çıktılarını hedefleyen çok kısıtlı sayıda araştırmaya rastlanmıştır (örn., Kawakami ve ark., 2007). Müdahale çalışmalarının çok büyük bir çoğunluğu tutum değişimini hedeflemektedir (örn., Carracosa ve ark., 2019 Tinkler ve ark., 2007) Elbette ki cinsiyetçi tutumların azaltılması cinsiyetçi davranışların azaltılması için gereklidir, ancak aralarındaki mekanizmanın tam anlamıyla anlaşılmadığı ve 
bu öğelerin her zaman birbirleriyle benzer yönde ve güçte ilişkili olmadığı göz önünde bulundurulduğunda, sadece tutum değişimini hedefleyen müdahaleler eksik kalmaktadir.

\section{TARTIŞMA}

Üç büyük kalıp yargı olarak adlandırılan 1rk, yaş ve cinsiyetin pek çok sosyal-bilişsel süreç üzerinde yüksek etki gücüne sahip olduğu bilinmektedir (Schneider, 2005). İnsanın diğerini algılaması ve izlenim oluşturması süreçlerinde cinsiyet hem çok hızlı hem de güçlü ve dirençli şekilde kaydedilir (Fiske, 1998; Kurzban ve ark., 2001). Bu çalışma, cinsiyet kalıp yargılarının yaşamın çeşitli alanlarındaki etkilerini konu alan araştırmaları ve cinsiyetçiliğe ilişkin geliştirilen müdahale çalışmalarını derlemeye ve araştırma sonuçları arasındaki tutarsızlıkları gidermeye yönelik bir sınıflandırma önerisi sunmayı amaçlamıştır.

Genel olarak cinsiyetçilik, gerek diğer sosyal psikolojik değişkenlerle ilişkileri açısından gerekse pek çok sosyal bilişsel mekanizmaya etkileri açısından sıklıkla incelenmiştir (Koepke, Eyssel ve Bohner, 2014; Sidanius, 1993). Cinsiyetçiliği azaltmaya yönelik müdahale araştırmalarının ise nispeten düşük oranda olduğu görülmektedir ve bu araştırmalarda hem kuramsal hem yöntemsel açıdan bir uzlaşmazlığın hakim olduğu ve adeta alanyazının aynı dili konuşmadığı görülmektedir. Bu durumun temel sebeplerinden biri müdahale çalışmalarında pek çok farklı kuramdan yalnızca birinin dikkate alınması olabilir. Örneğin, çelişik duygulu cinsiyetçilik kuramını temel alan Good ve Woodzicka’nın (2010) araştırmasında korumacı cinsiyetçiliğin tanınması zor bir yapı olduğu vurgulanarak bu yönde bir müdahale gerçekleştirilmiş ve başarılı olmuştur. Ardından Case ve arkadaşlarının (2014) araştırmasında ise, bağımlı değişkenlerden biri olarak çelişik duygulu cinsiyetçilik ölçümü alınsa da gerçekleştirilen müdahalelerde kuramın öngörüleri yeterince dikkate alınmamıştır ve çelişik duygulu cinsiyetçiliğin azaltılması yönünde bir sonuç elde edilmemiştir. Açık, gizil ve örtük cinsiyetçi tutumlarla ilgili yapılan araştırmalarda da benzer bir örüntüden söz edilebilir. Davranışı yordama açısından birlikte çalıştığı varsayılan bu iki yapı (Perugini, 2005) cinsiyetçiliğin tutum evresine yönelik müdahale geliştirmeyi amaçlayan pek çok araştırmada tekil olarak incelenmiştir (örn., Blair ve ark., 2001; Moss-Racusin ve ark., 2016). Bu noktada cinsiyetçilik alanyazınında görülen bir başka önemli eksiklik göze çarpmaktadır. Tutum davranış ilişkileri üzerine bildiklerimizin çok büyük bir çoğunluğu ırkçılık alanyazının- 
dan gelmektedir (örn., McConnell ve Leibold, 2001); özel olarak cinsiyetçi tutumlarda hangi yapının cinsiyetçi davranışı daha iyi yordadığı konusunda oldukça kısıtlı sayıda araştırma mevcuttur (örn., de Oliveira Laux ve ark., 2015). Oysa, bu ilişkinin belirlenmesi hem cinsiyetçiliğin mekanizmasının daha iyi anlaşılması açısından hem de geliştirilecek müdahalelerin başarı oranının ve etki gücünün artırılması açısından kritik bir öneme sahiptir.

Cinsiyetçiliği azaltmaya yönelik müdahale çalışmalarında göze çarpan diğer bir önemli eksiklik ise cinsiyetçiliğin tek boyutlu bütün bir yapı olarak ele alınması, içerdiği sosyal bilişsel mekanizmaların yeterince göz önünde bulundurulmamasıdır. Bu noktada burada önerilen sınıflandırma modeli, alanyazındaki çalışmaların ve gelecek çalışmaların organizasyonu için uygun bir temel oluşturabilir; cinsiyetçiliğin her bir boyutunun ayrı ayrı incelenmesi hem alanyazında ortak bir dil oluşması açısından hem de elde edilen sonuçların karşılaştırılabilir olması ve dolayısıyla kümülatif bir ilerleme sağlanması açısından fayda sağlayacaktır. Ayrıca, burada önerilen sınıflandırma modelinin öğelerinin birbiri üzerine inşa edilen, aşamalı evreler olarak ele alınması da mümkündür. Böylece cinsiyetçiliğe müdahale programlarının hiyerarşik bir model kapsamında ele alınmasına da olanak sağlayacaktır. Müdahalenin ardından her bir boyuta ilişkin çıktıların ayrı ayrı ölçülmesi müdahalenin etkilerine ilişkin daha detaylı bilgi sunacak, hangi boyutta müdahalenin etki gücünün daha yüksek olduğunun tespit edilmesini sağlayacaktır. Farklı boyutlar için farklı müdahale türlerinin farklılaşan etki güçleriyle başarılı olması şaşırtıcı olmayacaktır. Ancak alanyazında henüz böyle bir bakış açısı mevcut olmadığından özel olarak müdahale türlerinin etki ettikleri boyutlar ve etki güçleri yeterince açık değildir. Nitekim, burada önerilen modelin sağlayabileceği ciddi katkılardan biri de bu belirsizliğin giderilmesi olacaktır. Özetle, söz konusu sınıflandırma yaklaşımı gelecek çalışmalarda özel boyutlara yönelik müdahaleler geliştirilmesini sağlamak ve belirli bir müdahalenin aşamalı olarak etkilerini incelemek suretiyle alanyazında yer alan bulguların tutarsızlığının giderilmesine katkı sağlayacaktır.

Ülkemizde ise cinsiyetçiliğe yönelik müdahale çalışmalarında ciddi bir eksiklik olduğu göze çarpmaktadır. Her ne kadar konuya ilişkin hassasiyet düzeyi artma eğiliminde olsa da bu artışın büyük ölçüde sosyal bilimlerle ilgilenen kesimde gerçekleştiği ve toplumdaki diğer kurum ve yapılanmalara yeterince sirayet etmediği aşikardır. TÜİK'in yayımladığı 2019 verilerine göre, yaşadığı çevrede gece yalnız yürürken kadınların \%34'ü kendini güvensiz/çok güvensiz hissederken, bu oran erkekler için \%12 düzeyindedir. İstihdam oranları incelendiğinde ise çok daha çarpıcı veriler mevcuttur. Yine 
TÜİK' in 2019 verilerine göre, çocuksuz evlerde kadının istihdam oranı \%53, erkek için ise $\% 75$ 'tir. Evde çocuk olduğunda ise kadının istihdam oranı \%27'ye düşmekte, erkek için ise \%87'ye yükselmektedir (TÜİK, 2019). Ayrıca, ülkemizde cinsiyetçiliğin yansımalarından şiddet gibi trajik boyutlarının yaygınlığ 1 da göz önünde bulundurulduğunda, sosyal bilimler içinde psikoloji alanının bu konuda en az duyarlılık gösteren alan olması da ciddi bir sorundur (Bolak-Boratav, 2011; Boyacıŏglu, 2016). Ülkemizde, flört şiddetine yönelik önleyici bir müdahale çalışması (Üstünel, 2020), cinsiyet kalıp yargılarının gücünün nasıl azaltılabileceği yönünde ipuçları sunan bir araştırma (Kılıç ve ark., 2014) ve ziraat alanındaki istatistiklerde cinsiyet yanlılığının azaltılması yönünde öneriler sunan bir araştırma (Ayhan, 2001) dişında Türkiye'de gerçekleştirilmiş cinsiyetçiliği azaltmayı amaçlayan bir müdahale çalışmasına rastlanamamıştır. Öte yandan, ülkemizde genç araştırmacıların toplumsal cinsiyet ve cinsiyetçilik konularında artan ilgisi umut verici bir tablo sunmaktadır (Bolak-Boratav, 2021).

Son olarak, burada önerilen sınıflandırma modelinin temel amacı, cinsiyetçiliğe yapılan müdahale çalışmalarında her bir aşamanın ayrık olarak incelenmesi ve bu aşamalar arasındaki aktarımların açıklığa kavuşması suretiyle cinsiyetçiliğin azaltılması yönünde daha somut ve gerçekçi bulguların elde edilmesine olanak sağlamaktır.

Hakem Değerlendirmesi: Dış bağımsız.

Yazar Katkıları: Çalışma Konsepti/Tasarım- N.S.S., İ.M.T.; Veri Toplama- N.S.S., İ.M.T.; Veri Analizi/YorumlamaN.S.S., İ.M.T.; Yazı Taslağı- N.S.S., İ.M.T.; İçeriğin Eleştirel İncelemesi- N.S.S., İ.M.T.; Son Onay ve SorumlulukN.S.S., İ.M.T.

Çıkar Çatışması: Yazarlar çıkar çatışması bildirmemiştir.

Finansal Destek: Yazarlar bu çalışma için finansal destek almadığını beyan etmiştir.

Peer-review: Externally peer-reviewed.

Author Contributions: Conception/Design of Study- N.S.S., I.M.T.; Data Acquisition- N.S.S., İ.M.T.; Data Analysis/ Interpretation- N.S.S., İ.M.T.; Drafting Manuscript- N.S.S., İ.M.T.; Critical Revision of Manuscript- N.S.S., İ.M.T.; Final Approval and Accountability- N.S.S., İ.M.T.

Conflict of Interest: The authors have no conflict of interest to declare.

Grant Support: The authors declared that this study has received no financial support.

\section{Kaynakça/References}

Aberson, C. L. ve Haag, S. C. (2007). Contact, perspective taking, and anxiety as predictors of stereotype endorsement, explicit attitudes, and implicit attitudes. Group Processes \& Intergroup Relations, 10(2), 179-201. https://doi.org/10.1177/1368430207074726.

Agerström, J. ve Rooth, D. O. (2011). The role of automatic obesity stereotypes in real hiring discrimination. Journal of Applied Psychology, 96(4), 790-805. https://doi.org/10.1037/a0021594. Allport, G. W., Clark, K. ve Pettigrew, T. (1954). The nature of prejudice. Perseus Books. 
Armitage, C. J. ve Christian, J. (2003). From attitudes to behaviour: Basic and applied research on the theory of planned behaviour. Current Psychology, 22(3), 187-195.

Armitage, C. J. ve Conner, M. (2001). Efficacy of the theory of planned behaviour: A meta-analytic review. British Journal of Social Psychology, 40(4), 471-499.

Avcil, C. (2020). Kadın bedeni üzerinde denetim aracı olarak namus cinayetleri: Türkiye örneği. International Journal of Social and Humanities Sciences (IJSHS), 4(3), 137-150.

Ayhan, H. Ö. (2001). Statistics by gender: Measures to reduce gender bias in agricultural surveys. International Statistical Review, 69(3), 447-460.

Bargh, J. A., Chen, M. ve Burrows, L. (1996). Automaticity of social behavior: Direct effects of trait construct and stereotype activation on action. Journal of Personality and Social Psychology, 71, $230-244$.

Basford, T. E., Offermann, L. R. ve Behrend, T. S. (2014). Do you see what I see? Perceptions of gender microaggressions in the workplace. Psychology of Women Quarterly, 38(3), 340-349. https://doi. org/ 10.1177/0361684313511420.

Bem, S. L. (1981). Gender schema theory: A cognitive account of sex typing. Psychological Review, 88(4), 354-364.

Benokraitis, N. V. ve Feagin, J. R. (1995). Modern sexism: Blatant, subtle, and covert discrimination. Prentice Hall.

Berryman, K. L. (2020). Decreasing women's endorsement of benevolent sexism. (Yayımlanmamış Yüksek Lisans Tezi). Chicago: Loyola University.

Berthold, A., Steffens, M. C. ve Mummendey, A. (2019). What did they say? How subgroup stereotypes influence memory for superordinate groups. Journal of Experimental Social Psychology, 83, 23-36. https://doi.org/10.1016/j.jesp.2019.02.007.

Bilgin, N. (2014). Sosyal psikoloji (5. Bask1). Ege Üniversitesi Yayınları.

Blair, I. V. ve Banaji, M. R. (1996). Automatic and controlled processes in stereotype priming. Journal of Personality and Social Psychology, 70(6), 1142-1163.

Blair, I. V., Ma, J. E. ve Lenton, A. P. (2001). Imagining stereotypes away: the moderation of implicit stereotypes through mental imagery. Journal of Personality and Social Psychology, 81(5), 828-841. https://doi.org/10.1037//0022-3514.81.5.828.

Bodenhausen, G. V. (1990). Stereotypes as judgmental heuristics: Evidence of circadian variations in discrimination. Psychological Science, 1(5), 319-322.

Bolak-Boratav, H. (2011). Searching for feminism in psychology in Turkey. R. Rutherford, R. Capdevila, U. Vindhya, ve I. Palmary, (Ed.), Handbook of international feminisms: Perspectives on psychology, women, culture, and rights içinde (s. 17-36). Springer. https://doi.org/10.1007/9781-4419-9869-9_2.

Bolak-Boratav, H. (2021). Feminizm ve psikoloji: Sıkıntılı bir ilişki. Reflektif, 2 (1), 143-163. https:// doi.org/10.47613/reflektif.2021.19.

Boyacıoğlu, İ. (2016). Dünden bugüne Türkiye'de kadına yönelik şiddet ve ulusal kadın çalışmaları: Psikolojik araştırmalara davet. Türk Psikoloji Yazıları, 19, 126-145.

Bravo, M. J., Gilbert, L. A. ve Kearney, L. K. (2003). Interventions for promoting gender equitable technology use in classrooms. Teacher Education Quarterly, 30(4), 95-109.

Broverman, I. K., Broverman, D. M., Clarkson, F. E., Rosenkrantz, P. S. ve Vogel, S. R. (1970). Sexrole stereotypes and clinical judgments of mental health. Journal of Consulting and Clinical Psychology, 34, 1-7.

Broverman, I. K., Vogel, S. R., Broverman, D. M., Clarkson, F. E. ve Rosenkrantz, P. S. (1972). Sex-role 
stereotypes: A current appraisal. Journal of Social Issues, 28, 59-78. doi:10.1111/j.1540-4560.1972. tb00018.x.

Campbell, B., Schellenberg, E. G. ve Senn, C. Y. (1997). Evaluating measures of contemporary sexism. Psychology of Women Quarterly, 21(1), 89-102.

Carnes, M., Devine, P. G., Isaac, C., Manwell, L. B., Ford, C. E., Byars-Winston, A., ... ve Sheridan, J. (2012). Promoting institutional change through bias literacy. Journal of Diversity in Higher Education, 5(2), 63-77. https://doi.org/10.1037/a0028128.

Carrascosa, L., Cava Caballero, M. J., Buelga Vásquez, S. ve Jesus, S. N. D. (2019). Reduction of sexist attitudes, romantic myths, and aggressive behaviors in adolescents: Efficacy of the DARSI program. Psicothema, 2019, 31(2), 121-127. https://doi.org/10.7334/psicothema2018.245.

Case, K. A., Hensley, R. ve Anderson, A. (2014). Reflecting on heterosexual and male privilege: Interventions to raise awareness. Journal of Social Issues, 70(4), 722-740. https://doi.org/10.1111/ josi.12088.

Charlesworth, T. E., Yang, V., Mann, T. C., Kurdi, B. ve Banaji, M. R. (2021). Gender stereotypes in natural language: Word embeddings show robust consistency across child and adult language corpora of more than 65 million words. Psychological Science, 32(2), 218-240. https://doi. org/10.1177/0956797620963619.

Chen, M. ve Bargh, J. A. (1997). Non-conscious behavioral confirmation processes: The self-fulfilling consequences of automatic stereotype activation. Journal of Experimental Social Psychology, 33(5), 541-560.

Crenshaw, K. (1989). Demarginalizing the intersection of race and sex: A Black feminist critique of antidiscrimination doctrine, feminist theory and antiracist politics. University of Chicago Legal Forum, 1989, 139-167.

Cundiff, J. L., Zawadzki, M. J., Danube, C. L. ve Shields, S. A. (2014). Using experiential learning to increase the recognition of everyday sexism as harmful: The WAGES intervention. Journal of Social Issues, 70(4), 703-721. https://doi.org/10.1111/josi.12087.

Dang, H. A. H. ve Nguyen, C. V. (2021). Gender inequality during the COVID-19 pandemic: Income, expenditure, savings, and job loss. World Development, 140, 105296. https://doi.org/10.1016/j. worlddev.2020.105296.

Dasgupta, N. ve Asgari, S. (2004). Seeing is believing: Exposure to counterstereotypic women leaders and its effect on the malleability of automatic gender stereotyping. Journal of Experimental Social Psychology, 40(5), 642-658. https://doi.org/10.1016/j.jesp.2004.02.003.

de Lemus, S., Navarro, L., J. Velásquez, M., Ryan, E. ve Megías, J. L. (2014). From sex to gender: A university intervention to reduce sexism in Argentina, Spain, and El Salvador. Journal of Social Issues, 70(4), 741-762. https://doi.org/10.1111/josi.12089.

de Oliveira Laux, S. H., Ksenofontov, I. ve Becker, J. C. (2015). Explicit but not implicit sexist beliefs predict benevolent and hostile sexist behavior. European Journal of Social Psychology, 45(6), 702715. https://doi.org/10.1002/ejsp.2128.

Diekman, A. B., ve Eagly, A. H. (2000). Stereotypes as dynamic constructs: Women and men of the past, present, and future. Personality and Social Psychology Bulletin, 26(10), 1171-1188. https:// doi.org/10.1177/0146167200262001.

Devine, P. G. (1989). Stereotypes and prejudice: Their automatic and controlled components. Journal of Personality and Social Psychology, 56(1), 5-18.

Drury, B. J. ve Kaiser, C. R. (2014). Allies against sexism: The role of men in confronting sexism. Journal of Social Issues, 70(4), 637-652. https://doi.org/10.1111/josi.12083. 
Duehr,E.E.veBono,J.E.(2006).Men, women, and managers: arestereotypes finally changing? Personnel Psychology, 59(4), 815-846. https://doi.org/10.1111/j.1744-6570.2006.00055.x.

Eagly, A. H. ve Mladinic, A. (1989). Gender stereotypes and attitudes toward women and men. Personality and Social Psychology Bulletin, 15(4), 543-558.

Eagly, A. H. ve Steffen, V. J. (1984). Gender stereotypes stem from the distribution of women and men into social roles. Journal of Personality and Social Psychology, 46(4), 735-754.

ECOSOC U. (2019) Special edition: progress towards the sustainable development goals report of the secretary-general. Advanced unedited version. New York: United Nations.

Fazio, R. H. ve Olson, M. A. (2003). Implicit measures in social cognition research: Their meaning and use. Annual Review of Psychology, 54(1), 297-327. https://doi.org/10.1146/annurev. psych.54.101601.145225.

Fiske, S. T. (1998). Stereotyping, prejudice, and discrimination. Gilbert, D. T., Fiske, S. T. ve Lindzey G., (Ed.), The handbook of social psychology içinde (s. 357-411). McGraw-Hill.

Fredrickson, B. L. ve Roberts, T. A. (1997). Objectification theory: Toward understanding women's lived experiences and mental health risks. Psychology of Women Quarterly, 21(2), 173-206.

Freedman, G., Seidman, M., Flanagan, M., Kaufman, G. ve Green, M. C. (2018). The impact of an "aha" moment on gender biases: Limited evidence for the efficacy of a game intervention that challenges gender assumptions. Journal of Experimental Social Psychology, 78, 162-167. https:// doi.org/10.1016/j.jesp.2018.03.014.

Gaertner, S. L. ve Dovidio, J. F. (1986). The aversive form of racism. Academic Press.

Glick, P. ve Fiske, S. T. (1996). The ambivalent sexism inventory: Differentiating hostile and benevolent sexism. Journal of Personality and Social Psychology, 70(3), 491-512. https://doi. org/10.1037/0022-3514.70.3.491.

Glick, P. ve Fiske, S. T. (2001). An ambivalent alliance: Hostile and benevolent sexism as complementary justifications for gender inequality. American Psychologist, 56(2), 109-118. https:// doi.org/10.1037/0003-066X.56.2.109.

Glick, P. ve Fiske, S. T. (2011). Ambivalent sexism revisited. Psychology of Women Quarterly, 35(3), 530-535. https://doi.org/10.1177/0361684311414832.

Gocłowska, M. A., Crisp, R. J. ve Labuschagne, K. (2013). Can counter-stereotypes boost flexible thinking?. Group Processes \& Intergroup Relations, 16(2), 217-231. https://doi. org/10.1177/1368430212445076.

Good, J. J. ve Woodzicka, J. A. (2010). Reducing approval of benevolent sexism: An educational intervention. The New School Psychology Bulletin, 7(1), 16-30.

Greenwald, A. G. ve Banaji, M. R. (1995). Implicit social cognition: attitudes, self-esteem, and stereotypes. Psychological review, 102(1), 4-27.

Greenwald, A. G., Banaji, M. R. ve Nosek, B. A. (2015). Statistically small effects of the Implicit Association Test can have societally large effects. Journal of Personality and Social Psychology, 108(4), 553-561. https://doi.org/10.1037/pspa0000016.

Greenwald, A. G., McGhee, D. E. ve Schwartz, J. L. (1998). Measuring individual differences in implicit cognition: The Implicit Association Test. Journal of Personality and Social Psychology, 74(6), 1464-1480.

Greenwald, A. G., Poehlman, T. A., Uhlmann, E. L., ve Banaji, M. R. (2009). Understanding and using the Implicit Association Test: III. Meta-analysis of predictive validity. Journal of Personality and Social Psychology, 97(1), 17-41. https://doi.org/10.1037/a0015575.

Gupta, V. K., Turban, D. B. ve Bhawe, N. M. (2008). The effect of gender stereotype activation 
on entrepreneurial intentions. Journal of Applied Psychology, 93(5), 1053-1061. https://doi. org/10.1037/0021-9010.93.5.1053.

Hill, S. E. ve Flom, R. (2007). 18-and 24-month-olds' discrimination of gender consistent and inconsistent activities. Infant Behavior and Development, 30(1), 168-173. https://doi.org/10.1016/j. infbeh.2006.08.003.

Hilliard, L. J. ve Liben, L. S. (2010). Differing levels of gender salience in preschool classrooms: Effects on children's gender attitudes and intergroup bias. Child Development, 81(6), 1787-1798. https://doi.org/10.1111/j.1467-8624.2010.01510.x.

Hofmann, W., Gawronski, B., Gschwendner, T., Le, H. ve Schmitt, M. (2005). A meta-analysis on the correlation between the Implicit Association Test and explicit self-report measures. Personality and Social Psychology Bulletin, 31(10), 1369-1385. https://doi.org/10.1177/0146167205275613.

Hong, Z. R., Lin, H. S. ve Veach, P. M. (2008). Effects of an extracurricular science intervention on science performance, self-worth, social skills, and sexist attitudes of Taiwanese adolescents from single-parent families. Sex Roles, 59(7-8), 555-567. https://doi.org/10.1007/s11199-008-9453-z.

Huang, L. M. ve Sherman, J. W. (2018). Attentional processes in social perception. Advances in Experimental Social Psychology, 58, 199-241. https://doi.org/10.1016/bs.aesp.2018.03.002.

Hugenberg, K. ve Bodenhausen, G. V. (2004). Ambiguity in social categorization: The role of prejudice and facial affect in race categorization. Psychological Science, 15(5), 342-345. https://doi. org/10.1111/j.0956-7976.2004.00680.x.

Isaac, C., Lee, B. ve Carnes, M. (2009). Interventions that affect gender bias in hiring: A systematic review. Academic medicine: journal of the Association of American Medical Colleges, 84(10), 1440-1446. https://doi.org/10.1097/ACM.0b013e3181b6ba00.

Jackson, S. M. (2016). The influence of implicit and explicit gender bias on grading and the effectiveness of rubrics for reducing bias (Yayımlanmamış Doktora Tezi). Ohio: Wright State University.

Jost, J. T. ve Kay, A. C. (2005). Exposure to benevolent sexism and complementary gender stereotypes: Consequences for specific and diffuse forms of system justification. Journal of Personality and Social Psychology, 88, 498-509.

Kandiyoti, D. (1982). Kadınlarda psiko-sosyal değişim: Kuşaklar arasında bir karşılaştırma. türk toplumunda kadın. Sosyal Bilimler Araştırma Dizisi, 1, 311-339.

Kawakami, K., Dovidio, J. F. ve Kamp, S. (2007). The impact of counterstereotypic training and related correction processes on the application of stereotypes. Group Processes \& Intergroup Relations, 10(2), 139-156. https://doi.org/10.1177/1368430207074725.

Kılıç, A. Z., Beyazova, A., Akbaş, H. M., Zara, A., ve Serhatlı, İ. (2014). Okul çağı çocuklarının toplumsal cinsiyet algıları: Gündelik yaşam örnekleriyle cinsiyetçiliğin benimsenme durumuna ve esneyebilme olasılı̆̆ına dair bir araştırma. Sosyoloji Araştırmaları Dergisi, 17(2), 121-151. https:// doi.org/10.18490/sosars.379175.

Kilmartin, C., Semelsberger, R., Dye, S., Boggs, E. ve Kolar, D. (2015). A behavior intervention to reduce sexism in college men. Gender Issues, 32(2), 97-110. https://doi.org/10.1007/s12147-0149130-1.

Kilmartin, C., Smith, T., Green, A., Heinzen, H., Kuchler, M. ve Kolar, D. (2008). A real time social norms intervention to reduce male sexism. Sex Roles, 59(4), 264-273. https://doi.org/10.1007/ s11199-008-9446-y.

Klonoff, E. A., Landrine, H. ve Campbell, R. (2000). Sexist discrimination may account for well-known gender differences in psychiatric symptoms. Psychology of Women Quarterly, 24(1), 93-99. https:// doi.org/10.1111/j.1471-6402.2000.tb01025.x. 
Koepke, S., Eyssel, F. ve Bohner, G. (2014). "She Deserved It" effects of sexism norms, type of violence, and victim's pre-assault behavior on blame attributions toward female victims and approval of the aggressor's behavior. Violence Against Women, 20(4), 446-464. https://doi. org/10.1177/1077801214528581.

Koenig, L. B., McGue, M. ve Iacono, W. G. (2008). Stability and change in religiousness during emerging adulthood. Developmental Psychology, 44, 531-543. https://doi.org/10.1037/00121649.44.2.532.

Kosterina, E., Horne, S. G. ve Lamb, S. (2019). The role of gender-based violence, health worries, and ambivalent sexism in the development of women's gynecological symptoms. Journal of Health Psychology, 1359105318825292. https://doi.org/10.1177/1359105318825292.

Kray, L. J., Thompson, L. ve Galinsky, A. (2001). Battle of the sexes: Gender stereotype confirmation and reactance in negotiations. Journal of Personality and Social Psychology, 80(6), 942-958. https://doi.org/10.1037/0022-3514.80.6.942.

Krosnick, J. A. ve Alwin, D. F. (1989). Aging and susceptibility to attitude change. Journal of Personality and Social Psychology, 57, 416-425. https://doi.org/10.1037/0022-3514.57.3.416. Kurzban, R., Tooby, J. ve Cosmides, L. (2001). Can race be erased? Coalitional computation and social categorization. Proceedings of the National Academy of Sciences, 98(26), 15387-15392. https://doi.org/10.1073/pnas.251541498.

Lamb, L. M., Bigler, R. S., Liben, L. S. ve Green, V. A. (2009). Teaching children to confront peers' sexist remarks: Implications for theories of gender development and educational practice. Sex Roles, 61(6), 361-382. https://doi.org/10.1007/s11199-009-9634-4.

Lamont, R. A., Swift, H. J. ve Abrams, D. (2015). A review and meta-analysis of age-based stereotype threat: Negative stereotypes, not facts, do the damage. Psychology and Aging, 30(1), 180-193. https://doi.org/10.1037/a0038586.Lenton, A. P., Bruder, M. ve Sedikides, C. (2009). A meta-analysis on the malleability of automatic gender stereotypes. Psychology of Women Quarterly, 33(2), 183 196. https://doi.org/10.1111/j.1471-6402.2009.01488.x.

Liben, L. S. ve Coyle, E. F. (2014). Developmental interventions to address the STEM gender gap: Exploring intended and unintended consequences. Advances in Child Development and Behavior, 47, 77-115. https://doi.org/10.1016/bs.acdb.2014.06.001.

Lundeberg, M. A. (1997). You guys are overreacting: Teaching prospective teachers about subtle gender bias. Journal of Teacher Education, 48(1), 55-61. https://doi.org/10.1177/0022487197048001008.

Maccoby, E. E. ve Jacklin, C. N. (1974). Myth, reality and shades of gray-what we know and don't know about sex differences. Psychology Today, 8(7), 109-112. doi:10. 1037/e400662009-008.

McConahay, J. B. (1986). Modern racism, ambivalence, and the modern racism scale. J. F. Dovidio ve S. L. Gaertner (Ed.), Prejudice, discrimination, and racism içinde (s. 91- 125). Academic Press.

McConnell, A. R. ve Leibold, J. M. (2001). Relations among the Implicit Association Test, discriminatory behavior, and explicit measures of racial attitudes. Journal of Experimental Social Psychology, 37(5), 435-442. https://doi.org/10.1006/jesp.2000.1470.

McKimmie, B. M., Masters, J. M., Masser, B. M., Schuller, R. A. ve Terry, D. J. (2013). Stereotypical and counterstereotypical defendants: Who is he and what was the case against her?. Psychology, Public Policy, and Law, 19(3), 343-354. https://doi.org/10.1037/a0030505.

Mehl, M. R., Vazire, S., Ramírez-Esparza, N., Slatcher, R. B. ve Pennebaker, J. W. (2007). Are women really more talkative than men?. Science, 317(5834), 82-82. https://doi.org/10.1126/ science. 1139940.

Meyer, E. J. (2008). Gendered harassment in secondary schools: Understanding teachers'(non) 
interventions. Gender and Education, 20(6), 555-570. https://doi.org/10.1080/09540250802213115.

Monteith, M. J. (1993). Self-regulation of prejudiced responses: Implications for progress in prejudicereduction efforts. Journal of Personality and Social Psychology, 65(3), 469-485.

Mora, N. (2006). Kitle iletişim araçlarında yeniden üretilen cinsiyetçilik ve toplumda yansıması. Journal of Human Sciences, 2(1), 1-7.

Moss-Racusin, C. A., van der Toorn, J., Dovidio, J. F., Brescoll, V. L., Graham, M. J. ve Handelsman, J. (2016). A "scientific diversity" intervention to reduce gender bias in a sample of life scientists. CBE-Life Sciences Education, 15(3), 1-11. https://doi.org/10.1187/cbe.15-09-0187.

Navarro-Pérez, J. J., Oliver, A., Carbonell, Á. ve Schneider, B. H. (2020). Effectiveness of a mobile app intervention to prevent dating violence in residential child care. Psychosocial Intervention, 29(2), 59-66. https://doi.org/10.5093/pi2020a3.

Newall, C., Gonsalkorale, K., Walker, E., Forbes, G. A., Highfield, K. ve Sweller, N. (2018). Science education: Adult biases because of the child's gender and gender stereotypicality. Contemporary Educational Psychology, 55, 30-41. https://doi.org/10.1016/j.cedpsych.2018.08.003.

Nosek, B. A. (2005). Moderators of the relationship between implicit and explicit evaluation. Journal of Experimental Psychology, 134(4), 565-584. https://doi.org/10.1037/0096-3445.134.4.565.

Owen, J., Tao, K. ve Rodolfa, E. (2010). Microaggressions and women in short-term psychotherapy: Initial evidence. The Counseling Psychologist, 38(7), 923-946. https://doi. org/10.1177/0011000010376093.

Parker, L. R., Monteith, M. J., Moss-Racusin, C. A. ve Van Camp, A. R. (2018). Promoting concern about gender bias with evidence-based confrontation. Journal of Experimental Social Psychology, 74, 8-23. https://doi.org/10.1016/j.jesp.2017.07.009.

Perugini, M. (2005). Predictive models of implicit and explicit attitudes. British Journal of Social Psychology, 44(1), 29-45. https://doi.org/10.1348/014466604X23491.

Proverbio, A. M., Alberio, A. ve De Benedetto, F. (2018). Neural correlates of automatic beliefs about gender stereotypes: Males are more prejudicial. Brain and Language, 186, 8-16. https://doi. org/10.1016/j.bandl.2018.08.006.

Proverbio, A. M., Orlandi, A. ve Bianchi, E. (2017). Electrophysiological markers of prejudice related to sexual gender. Neuroscience, 358, 1-12. https://doi.org/10.1016/j.neuroscience.2017.06.028.

Ramos, M. R., Barreto, M., Ellemers, N., Moya, M., Ferreira, L. ve Calanchini, J. (2016). Exposure to sexism can decrease implicit gender stereotype bias. European Journal of Social Psychology, 46(4), 455-466. https://doi.org/10.1002/ejsp.2165.

Rinehart, J. W. (1963). The meaning of stereotypes. Theory into Practice, 2(3), 136-143.

Rosenthal, G. G. (2017). Mate choice: The evolution of sexual decision making from microbes to humans. Princeton University Press.

Rudman, L. A. ve Glick, P. (2008). The social psychology of gender: How power and intimacy shape gender relations. Guilford Press.

Sagone, E., De Caroli, M. E., Coco, R. F. M. ve Perciavalle, V. (2018). Flexibility of gender stereotypes: Italian study on comparative gender-consistent and gender-inconsistent information. Educational Psychology, 24(2), 93-98. https://doi.org/10.5093/psed2018a14.

Sakall1-Uğurlu, N. (2002). Çelişik Duygulu Cinsiyetçilik ölçeği: Geçerlik ve güvenirlik çalışması. Türk Psikoloji Dergisi, 17(49), 47-58.

Sakallı-Uğurlu, N. (2003). Cinsiyetçilik: Kadınlara ve erkeklere ilişkin tutumlar ve çelişik duygulu cinsiyetçilik kuramı. Türk Psikoloji Yazıları, 6(12), 1-20.

Schneider, D. J. (2005). The psychology of stereotyping. New York: Guilford Press. 
Shields, S. A., Zawadzki, M. J. ve Johnson, R. N. (2011). The impact of the Workshop Activity for Gender Equity Simulation in the Academy (WAGES-Academic) in demonstrating cumulative effects of gender bias. Journal of Diversity in Higher Education, 4(2), 120-129. https://doi. org/10.1037/a0022953.

Sidanius, J. (1993). The interface between racism and sexism. The Journal of Psychology, 127(3), 311322. https://doi.org/10.1080/00223980.1993.9915565.

Skowronski, J. J. ve Lawrence, M. A. (2001). A comparative study of the implicit and explicit gender attitudes of children and college students. Psychology of Women Quarterly, 25(2), 155-165. https:// doi.org/10.1111/1471-6402.00017.

Soylu, N. S. (2017). Spontane kişilik özelliği çıkarımları ve cinsiyet stereotipleri (Yayımlanmamış Yüksek Lisans Tezi). Ege Üniversitesi: İzmir.

Spence, J. T. ve Hahn, E. D. (1997). The attitudes toward women scale and attitude change in college students. Psychology of Women Quarterly, 21, 17-34. https://doi.org/10.1111/j.1471-6402.1997. tb00098.x.

Spence, J. T., Helmreich, R. L. ve Stapp, J. (1974). The Personal Attributes Questionnaire: A measure of sex role stereotypes and masculinity-femininity. Catalog of Selected Documents in Psychology, 4, 43-44.

Spence, J. T., Helmreich, R. ve Stapp, J. (1975). Ratings of self and peers on sex role attributes and their relation to self-esteem and conceptions of masculinity and femininity. Journal of personality and social psychology, 32, 29-39. https://doi.org/10.1037/h0076857.

Sue, D. W. (2010). Microaggressions in everyday life: Race, gender, and sexual orientation. John Wiley \& Sons.

Swim, J. K., Aikin, K. J., Hall, W. S. ve Hunter, B. A. (1995). Sexism and racism: Old-fashioned and modern prejudices. Journal of Personality and Social Psychology, 68(2), 199-214. https://doi. org/10.1037/0022-3514.68.2.199.

Swim, J. K. ve Campbell, B. (2003). Sexism: Attitudes, beliefs, and behaviors. R. Brown ve S. Gaertner, (Ed.), Blackwell handbook of social psychology: Intergroup processes içinde (ss. 218237). Blackwell Publishing.

Swim, J. K., Hyers, L.L., Cohen, L. L. ve Ferguson, M. J. (2001). Everyday sexism: Evidence for its incidence, nature, and psychological impact from three daily diary studies. Journal of Social Issues, 57, 31-53. https://doi.org/10.1177/0095798402239228.

Taub, N. (1985). Dealing with employment discrimination and damaging stereotypes: A legal perspective. Journal of Social Issues, 41(4), 99-109. https://doi.org/10.1111/j.1540-4560.1985. tb01144.x.

Tinkler, J. E., Li, Y. E., ve Mollborn, S. (2007). Can legal interventions change beliefs? The effect of exposure to sexual harassment policy on men's gender beliefs. Social Psychology Quarterly, 70(4), 480-494. https://doi.org/10.1177/019027250707000413.

Todorov, A. ve Uleman, J. S. (2003). The efficiency of binding spontaneous trait inferences to actors' faces. Journal of Experimental Social Psychology, 39(6), 549-562. https://doi.org/10.1016/S00221031(03)00059-3.

Tougas, F., Brown, R., Beaton, A. M. ve Joly, S. (1995). Neosexism: Plus ça change, plus c'est pareil. Personality and Social Psychology Bulletin, 21(8), 842-849. https://doi. org/10.1177/0146167295218007.

Türkiye İstatistik Kurumu (TÜİK, 2019). Toplumsal yapi ve cinsiyet istatistikleri. Erişim adresi: https:// data.tuik.gov.tr/Kategori/GetKategori?p=Nufus-ve-Demografi-109 
Twenge, J. M. (1997). Changes in masculine and feminine traits over time: A meta-analysis. Sex Roles, 36(5-6), 305-325. https://doi.org/10.1007/BF02766650.

Uleman, J. S., Saribay, S. A. ve Gonzalez, C. M. (2008). Spontaneous inferences, implicit impressions, and implicit theories. Annual Review of Psychology, 59, 329-360. https://doi.org/10.1146/annurev. psych.59.103006.093707.

Üstünel, A. O. (2020). A feminist approach to dating violence prevention: Creating change towards safety, equality and mutuality. Feminism \& Psychology, 30(2), 143-164. https://doi. org/10.1177/0959353519882462.

Wilson, T. D., Lindsey, S. ve Schooler, T. Y. (2000). A model of dual attitudes. Psychological Review, 107(1), 101-126. https://doi.org/10.1037/0033-295X.107.1.101.

Winter, L. ve Uleman, J. S. (1984). When are social judgments made? Evidence for the spontaneousness of trait inferences. Journal of Personality and Social Psychology, 47(2), 237-252. https://doi. org/10.1037/0022-3514.47.2.237.

Yan, X., Wang, M. ve Zhang, Q. (2012). Effects of gender stereotypes on spontaneous trait inferences and the moderating role of gender schematicity: Evidence from Chinese undergraduates. Social Cognition, 30(2), 220-231. https://doi.org/10.1521/soco.2012.30.2.220.

Yüksel-Kaptanoğlu, İ., Arslan, H. ve Akyıldırım, O. (2021). Toplumsal cinsiyet eşitliğine duyarlı veri ve göstergeler. Cinsiyet Eşitliği İzleme Derneği Yayınları. Erişim adresi: https://dspace.ceid. org.tr/xmlui/bitstream/handle/1/1415/E\%C4\%9Fitim\%20Materyali\%20-\%20Veri\%20ve\%20 G\%C3\%B6stergeler\%20SON.pdf?sequence $=4 \&$ is Allowed $=\mathrm{y}$

Zárate, M. A., Uleman, J. S. ve Voils, C. I. (2001). Effects of culture and processing goals on the activation and binding of trait concepts. Social Cognition, 19(3), 295-323. https://doi.org/10.1521/ soco.19.3.295.21469. 
